\title{
BEING THE NEW YORK TIMES: THE POLITICAL BEHAVIOUR OF A NEWSPAPER*
}

\author{
Riccardo Puglisi \\ Department of Political Science \\ Massachusetts Institute of Technology
}

$\mathrm{PEPP} / 20$

April 2006

Political Economy and Public Policy Series The Suntory Centre

Suntory and Toyota International Centres for Economics and Related Disciplines London School of Economics and Political Science Houghton Street London WC2A 2AE

Tel: (020) 79556674

\footnotetext{
*Email address: rpuglisi@mit.edu. I would like to thank my supervisor Andrea Prat for his constant encouragement and help. Moreover, I have greatly benefited from conversations with Bharat Anand, Heski Bar-Isaac, Tim Besley, Jordi Blanes i Vidal, Robin Burgess, Stefano DellaVigna, Dave Donaldson, Lucy Eyre, Carlo Fiorio, Christian Huse, Bryan Jones, Dean Karlan, Larry Kenny, Valentino Larcinese, John Lott, Maxwell McCombs, Adam Meirowitz, Silvia Pezzini, Steve Pischke, Imran Rasul, Ken Scheve, Jim Snyder, David Strömberg and Daniel Sturm. A special thank to Oriana Bandiera and Barbara Petrongolo. I would also like to thank seminar participants at the LSE/EOPP workshop, the LSE Government Seminar, the Silvaplana 2004 Workshop in Political Economy, the APSA 2004, the SEA 2004 and the 2005 Public Choice Conferences. All errors remain of course mine.
}

The paper is also available at:http://papers.ssrn.com/sol3/papers.cfm?abstract_id=573801 


\begin{abstract}
I analyze a dataset of news from the New York Times, from 1946 to 1997. Controlling for the incumbent President's activity across issues, I find that during the presidential campaign the New York Times gives more emphasis to topics that are owned by the Democratic party (civil rights, health care, labor and social welfare), when the incumbent President is a Republican. This is consistent with the hypothesis that the New York Times has a Democratic partisanship, with some "watchdog" aspects, in that -during the presidential campaign- it gives more emphasis to issues over which the (Republican) incumbent is weak. In the post-1960 period the Times displays a more symmetric type of watchdog behaviour, just because during presidential campaigns it gives more more coverage to the typically Republican issue of Defense when the incumbent President is a Democrat, and less so when the incumbent is a Republican.
\end{abstract}

JEL Nos.: D72, D78, L82

Keywords: News, media, information, elections, media bias, New York Times, issue ownership

(C) The author. All rights reserved. Short sections of text, not to exceed two paragraphs, may be quoted without explicit permission provided that full credit, including $\odot$ notice, is given to the source 


\section{Introduction}

It is a commonly held view that mass media play a crucial role in the political and electoral process ${ }^{1}$. This is the case because mass media, in their quality of news providers, offer readers and viewers pieces of information about the current state of affairs, incumbent politicians' performance and the behaviour of candidates during electoral campaigns.

This paper is the first to present evidence on the editorial choices of the New York Times, using a large sample of stories published between 1946 and 1997.

According to the theory of agenda-setting effects, mass media outlets can influence the agenda of the public, by tilting it towards those issues that they decide to cover more extensively. As vividly described by Cohen [1963], the press "[...] may not be successful much of the time in telling people what to think, but it is stunningly successful in telling its readers what to think about. The world will look different to different people depending on the map that is drawn for them by writers, editors, and publishers of the paper they read."

Such agenda-setting ability could have relevant electoral effects, to the extent that citizens on average think that a given party or candidate is more capable of handling problems related to a given issue, and would vote for that party if such issue turns out to be the most salient one. This is the issue ownership hypothesis, as characterised by Petrocik [1996].

However, there is very little evidence on whether and how mass media make use of their agenda-setting power. In particular, it is natural to ask whether a newspaper or a TV news broadcast systematically changes its coverage of issues during electoral campaigns, by tilting it towars topics over which a given political party is perceived as more capable by the majority of citizens. This would be consistent with the said newspaper being partisan in favour of that party.

During the electoral campaign a newspaper could behave differently as a function of the political affiliation of the incumbent government. It could in fact act as a watchdog, by differentially giving less coverage to issues over which the incumbent government's party is perceived as strong. Or vice versa it could act as a lapdog, by devoting more space to those issues which are owned ${ }^{2}$ by the incumbent's party. Finally, it would be relevant to understand whether outside of the electoral campaign the newspaper gives more coverage to topics owned by the incumbent government's party, controlling for the government's activity on these issues.

I answer these questions by analysing a large dataset of stories on the New York Times, and focusing my attention on U.S. presidential campaigns. This random sample of articles on the Times was collected by Frank Baumgartner, Bryan Jones and John Wilkerson within the Policy Agendas Project and classified according to the major topic being addressed. Within the set of coded topics, I classify a given topic as being owned by the Republican or the Democratic party if a majority of

\footnotetext{
${ }^{1}$ See e.g. DellaVigna and Kaplan [2005] for an estimate of the effects of the introduction of Fox News on the Republican vote at presidential elections.

${ }^{2}$ In accord with Petrocik [1996], I define an issue as owned by a given political party if a majority of citizens believes that this party is better able to handle problems related to it than its opponent(s).
} 
citizens believes that such party is better at handling problems related to it than the opponent.

My main finding is that the New York Times has a Democratic partisanship, with some watchdog aspects, in that during the presidential campaign it systematically gives more emphasis to Democratic topics, but only so when the incumbent President is a Republican. This set of Democratic topics comprises stories about civil rights, health care, labor and employment, and social welfare.

This effect of more stories about Democratic issues during the presidential campaign is sizeable: when the incumbent President is a Republican, there are 26 percent more stories about Democratic issues during the three months of the campaign than outside of it. The increase is actually larger (around 33 percent) when one considers the period starting from the 60s. On the contrary, if the incumbent President is a Democrat, there is no discernible change in the count of Democratic stories when the presidential campaign starts. This is true both for the entire sample and for the post-1960 subperiod, and is consistent with the fact that the partisan effect and the watchdog effect almost cancel each other.

The typical claim in the issue ownership literature is that the Republican party owns the issues of crime and defense. In fact, an analysis of Gallup polls and the National Election Study (NES) shows that this is indeed the case for defense, as in only three campaign years over a total of twelve there is a reversal in the ownership of the issue. On the other hand, in three cases out of seven (a shorter time series of polls is available here) was the Democratic party perceived as more competent than the GOP on the crime issue. Therefore I separately analyze the coverage of the two topics on the Times. If one considers the entire time span (from 1946 to 1997), one cannot find any systematic variation in the count of stories about these two topics during the presidential campaign. This asymmetric behaviour on Democratic and Republican topics during presidential campaigns is indeed consistent with a Democratic partisanship of the New York Times.

However, when restricting the attention to the 1961-1997 subsample, it turns out that the New York Times systematically gives more room to stories about Defense during the presidential campaign, when the incumbent president is a Democrat and there is no reversal in the ownership of the issue. Just because the ownership reversal occurs in 1964, 1980 and 1996, this effect would account for the 1968 campaign. When there is ownership reversal the Times ceteris paribus dedicates less room to Defense stories during the presidential campaign. Moreover, under the incumbency of a Republican President there is actually a decrease in the count of stories about Defense as the presidential campaign starts. Taken together, these findings are consistent with a watchdog attitude of the Times, in that during the presidential campaign there is less coverage of the defense issue when the incumbent President is perceived as more competent on it than the opponent. Regarding the Law \& Crime issue, there is no comparable pattern of change in the coverage, both for the entire time period and the post-1960 subsample.

Given the more symmetric behaviour with respect to Democratic topics and the Defense issue, the evidence regarding the 1961-1997 period lends more support to the hypothesis that the Times is a watchdog newspaper, and somewhat detracts from the Democratic partisanship hypothesis. 
In the interpretation of the econometric results, it is necessary to check whether any time variation in the choice of stories by the New York Times is in fact mirroring some contemporaneous variation in the activity of other political actors, and in particular of the incumbent President. As a proxy for the intensity of presidential activity on a given subset of issues at a given time, I use the relative frequency of Executive Orders concerning these issues, which are enacted by the incumbent President during the time period.

Controlling for this proxy of presidential activity across issues, it turns out that -outside of the presidential campaign- still the Times systematically gives more coverage to Democratic issues when the incumbent President is a Democrat, and to Defense stories when he is a Republican. This finding about Democratic stories helps understand the previous results: when the incumbent President is a Democrat, the aggregate count of stories about Democratic topics is already high outside the presidential campaign, and the presidential campaign does not produce any additional effect.

Such pattern of correlations does hold for both the entire sample and post-1960 period, where the magnitude and significance of the effect is stronger for Defense stories. On the other hand, there is no statistically significant correlation between the political affiliation of the President and the coverage of the Law \& Crime issue.

There are two key identifying assumptions which substantiate my empirical analysis. The first assumption is that the issue ownership hypothesis is correct. In other terms, the induced salience of an issue would give an electoral advantage to a given candidate, to the extent that there is a majority of voters who believe this candidate to be better at handling it, than his opponent.

The second assumption can be summarised by the statement: "all publicity is good publicity". The idea is that any story regarding an issue owned by a given candidate or party, no matter how negative, would not induce readers to change their perception about the ownership of the issue itself.

This analysis of the issue coverage by the New York Times contributes to the growing empirical literature on mass media bias, which I review in section 2.2. My approach is novel in three distinct ways:

1. I am interested in the agenda-setting behaviour of the newspaper, i.e. in its coverage of various policy issues. The agenda-setting framework, coupled with the issue ownership hypothesis, provides an intuitive way to think about the political stance of the newspaper.

2. My focus is on the time variation of the issue coverage by the Times, and in particular on how such coverage changes during presidential campaigns.

3. Given the time series framework and the sample length, I am able to investigate the differential behaviour of the Times during the presidential campaign as a function of the political affiliation of the incumbent President. I use the definitions of lapdog and watchdog to classify such differential behaviour.

As a collateral result, my paper contributes to the literature itself on issue ownership, by presenting survey data from Gallup and the National Election Study 
which cover a much longer time period than the one explicitly analyzed by Petrocik. The data gathered here broadly confirm, with some qualifications, the issue ownership pattern suggested by Petrocik.

The paper is organised as follows: in section 2 I discuss some related literature; section 3 describes the dataset. In section 4 I present the empirical strategy. Section 5 discusses the results, with some robustness checks and refinements. Section 6 confronts the findings with the theoretical literature on mass media bias and concludes.

\section{Related literature}

\subsection{Evidence on the agenda setting hypothesis}

The theory of agenda setting effects is built around the idea that mass media can influence the importance readers and viewers attach to different issues ${ }^{3}$. As Lippmann [1922] notes, pieces of news provided by mass media outlets are a primary source of information, and sometimes the only one, about public affairs: in the lack of information provided by mass media, most events related to public affairs would indeed be "out of reach, out of sight, out of mind" for the large majority of citizens. Hence editors and journalists can have relevant degrees of freedom in the choice of what is newsworthy, and this way they are able to influence the perception of citizens about which issues are relevant and to what extent.

McCombs and Shaw [1972] is the seminal empirical contribution in which the theory of agenda-setting effects has been put to test: during the 1968 US presidential election, a sample of voters in Chapel Hill, Carolina, was asked to mention what were the key issues of the campaign. These reported rankings were matched with the pattern of news coverage by newspapers and network television news in the previous month: the found correlation between these measures of the media and the public agenda was always positive and typically very large.

In fact, after McCombs and Shaw [1972], there has been a host of empirical studies striving to test for the presence of agenda-setting effects, either replicating their simple correlation exercise, or adopting more sophisticated empirical designs, ranging from cross sectional and longitudinal to experimental ones.

Experimental evidence, as the one provided by Iyengar et al. [1982], lends the strongest support to the agenda setting hypothesis. Both the treatment and the control group agreed to view what were alleged to be recordings of the previous evening's TV news programme: those in the control group watched the original programme, while individuals in the treatment viewed an altered version of it, with increased coverage of a given national issue. Before and after the experiment, individuals in both groups were administered a questionnaire about the most important problem. Controlling for the ex ante personal agenda, individuals in the treatment group systematically attached a higher ex post importance to the issue whose media coverage had been magnified.

\footnotetext{
${ }^{3}$ For more detailed surveys about the literature on agenda-setting effects, see Erbring, Goldenberg and Miller [1980], Iyengar, Kinder and Peters [1982], Iyengar and Simon [2000] and McCombs [2002].
} 
The choice itself of the topics being covered by the news media could produce electoral effects, to the extent that voters on average reckon candidates belonging to a given party as more capable of handling a given issue. This is the concept of issue ownership, as introduced by Petrocik [1996]. Analyzing news content, answers to open-ended questions about issue salience, and the vote itself for presidential elections between 1960 and 1992, Petrocik shows that candidates tend to emphasize owned issues in their political speeches. Secondly, given that issues owned by the Democratic (Republican) party are salient, turnout of Republicans (Democrats) tends to decrease, while the opposite holds for Democrats (Republicans). Moreover, Independents vote more for the Democratic (Republican) candidate.

Apart from these survey-based results, Ansolabehere and Iyengar [1994] present some experimental evidence about issue ownership effects. According to their study of the 1992 senatorial and presidential campaign in California, viewers of televised political ads were more likely to express a voting preference for the candidate that dealt with the owned issue rather than the same candidate dealing with the nonowned one, in this case the Republican discussing crime instead of unemployment, and vice versa for a Democrat.

\subsection{Evidence on the political behaviour of mass media}

Compared with the dense literature on agenda setting, there are very few empirical studies about the actual political behaviour of mass media outlets, which go beyond anedoctal evidence ${ }^{4}$. All these studies are quite recent, and share the common approach of disregarding the link between media content and public opinion, which is the primary focus of the literature on agenda setting effects, in order to focus the analysis on the behaviour itself of mass media outlets as political actors.

Groseclose and Milyo [2005] use a subtle cross-sectional design in order to estimate the relative position of mass media outlets in the political spectrum. The idea is to trace out which think tanks are quoted by various mass media outlets within news stories; in turn, the position of each think tank in the political spectrum is calculated as the weighted sum of the adjusted ADA scores of those representatives in the House and in the Senate that quote it in a non negative way. Using this procedure, the authors obtain the stark result that all sampled news providers -except Fox News' Special Report and the Washington Times- are located to the left of the average Congress member, i.e. there are signs of a liberal bias in the US news media. However, the news media also show a remarkable degree of centrism, in the sense that "[...] all outlets but one have ADA scores between the average Democrat and average Republican in Congress." And it turns out that the only media outlet that is located to the left of the average Democrat -in terms of think tank quotes within news stories- is the Wall Street Journal.

Regarding the New York Times, Groseclose and Milyo estimate an adjusted ADA score of 73.7 (maximum likelihood estimation). (Adjusted) ADA scores attribute a larger score to more liberal congressmen, on a 0-100 scale. Just to have a rough

\footnotetext{
${ }^{4}$ For a conservative author looking for (and finding) a systematic liberal bias in the mass media, see Goldberg [2002]. In a specular fashion, see Franken [2003] for a liberal approach correspondingly finding some conservative bias in the media.
} 
idea of the relative position of the New York Times, the score for Joe Lieberman (D, Ct.) is 74.2, while the score for Constance Morella (R, Md.) is 68.2.

Ansolabehere, Lessem and Snyder [2004] analyze the political orientation of endorsements by U.S. newspapers, using a panel data design. There is an upward trend in the average propensity to endorse a candidate, and in particular an incumbent one. There are also some changes in the average ideological slant of endorsements: while in the 40s and in the 50s there was a clear advantage to Republican candidates, this advantage continuously eroded in subsequent decades, to the extent that in the 90s the authors find a slight Democrats' lead in the average endorsement choice. In particular, an unquestionable Democratic slant in the endorsement choices of the New York Times in the TriState area (Connecticut, New Jersey and New York) emerged in the first half of the 70s, while during the 40s, 50s and 60s there was a slight advantage to Republican candidates. It is however true that in New York State the Times endorsed more Democratic than Republican candidates already as of the second half of the 50s.

Lott and Hassett [2004] study the coverage of economic news by a panel of 389 U.S. newspapers from 1991 to the first half of 2004, and from 1985 to 2004 for a subsample comprising the top 10 newspapers and the Associated Press. For each release of official data about a set of economic indicators, the authors analyze how newspapers decide to report on them, as reflected by the tone of the related headlines. The idea is to check whether newspapers display some kind of partisan bias, by giving more positive or negative coverage to the same economic datum, as a function of the political affiliation of the incumbent President. Controlling for the economic data being released, the authors find that there are between 9.6 and 14.7 percent fewer positive stories when the incumbent President is a Republican.

Regarding the New York Times, for the 1985-2004 period the authors find a similar pattern of fewer positive stories under a Republican incumbent, but such effect is mildly significant (at the $10 \%$ confidence level) only in one specification.

The empirical approach adopted by Lott and Hassett is close to the one I follow here, because of this common focus on the time series behaviour of news providers. However, their analysis is chiefly based on the correlation between the political affiliation of the incumbent President and the average tone adopted by newspapers in the coverage of economic news, with a minor role played by presidential elections and campaigns.

\subsection{Theories on mass media bias}

Within the field of political economy, there is a growing theoretical literature on mass media bias, and in general on the political behaviour of mass media. The common scope of this literature is to understand the reasons why in equilibrium profit-maximizing media outlets would -through their editorial choices- favor a given party or candidate.

Mullainathan and Shleifer [2005] suggest a demand-driven interpretation of this. The crucial behavioural assumption is that readers and viewers hold beliefs that they would like to see confirmed by news providers. When news customers share common beliefs, profit-maximizing media outlets find it optimal to select and/or 
frame stories in order to pander to those beliefs. On the other hand, when beliefs are heterogenous, news providers differentiate their offer and segment the market, by providing news stories that are slanted towards the two extreme positions in the spectrum of beliefs.

Gentzkow and Shapiro [2006] present another demand-driven theory of mass media bias, which however does not rely on behavioural assumptions. If readers and viewers are Bayesian updaters, have a priori views on the state of the world and are uncertain about the quality of the information about it being provided by media outlets, then the latter have an incentive to slant stories towards their customers' prior, in order to build and keep a reputation for high-quality journalism. The reason for this is that Bayesian agents would tend to believe that pieces of information that go against their prior in fact originate from low-quality news providers.

Baron [2006] proposes a supply-driven explanation for a persistent media bias, i.e. for a generalised slant of media outlets in favor of a given political position. This is the case if journalists, which are an essential input for news production, are characterised by a common ideological stance, i.e. they are all on average conservatives or liberal. It follows that media outlets maximise profits by slanting news stories towards the political bias of journalists, in order to benefit from a lower wage being demanded by the latter in equilibrium.

The three models discussed above share the common assumption of profit maximization by news providers. In a different context, Besley and Prat [2005] build a model in which mass media capture by the incumbent government (that translates into suppression of unfavorable news) takes place because media outlets trade off profits from sales and advertising against a direct or indirect bribe from the government itself. In this model the profit-maximization assumption is kept, but two different sources of income are traded off by media outlets.

In fact, the main alternative explanation for media bias is that the owners themselves have political preferences that are traded off against the pure profit maximization motive. Depending on the relative strength of these two motivations, a more or less intense slant of the news towards the owner's political preferences would emerge in equilibrium 5 .

\section{Data description}

\subsection{Evidence on issue ownership}

The seminal contribution in the issue ownership literature is Petrocik [1996]. In fact, all subsequent contributions that are based on an issue ownership hypothesis grossly take as given Petrocik's partition of issues into Democratic, Republican and performance ones ${ }^{6}$. However, Petrocik [1996] substantiates such a classification with survey data covering a short time period, which spans from 1988 to 1991 only. It is therefore empirically unclear whether the ownership status of policy issues, as stated by Petrocik, is indeed a long-term phenomenon.

\footnotetext{
${ }^{5}$ See Sutter [2001] for a discussion along these lines.

${ }^{6}$ See Ansolabehere and Iyengar [1994], Feeley [2001], Benoit, Hansen and Petrocik [2003].
} 
My contribution to this literature is to collect survey data on issue ownership which cover a longer time period than Petrocik's. Using Gallup surveys, and the National Election Study when Gallup data is not available, I am able to gather issue ownership percentages ${ }^{7}$ that date back to 1972 for the issues of social welfare and crime, to 1956 for civil rights, and to 1948 for defense. These data are presented in Table 1.

I use Gallup polls as the primary source of information, because of the more direct way its questions about issue ownership are worded, when compared with the NES. The typical Gallup format is to ask respondents about which party or candidate they think is better at handling a given issue; thus, the question itself specifies the issue about which respondents must express their opinion.

By contrast, one can obtain information about issue ownership from the NES only in a indirect fashion. Since 1960 the NES has administered a question about what the most important problem facing the country. Starting from 1972, this question about the most important problem (henceforth, MIP) has been coupled with one about "[...]which political party [...]would be most likely to get the government to do a better job in dealing with this problem [... ${ }^{\prime 8}$. Such survey design could suffer from a selection bias (unobservable factors determining the answer to the MIP question could be correlated with factors affecting the answer to the ownership one), and from a low degree of statistical reliability, given the possibly small number of respondents naming a given issue as the most salient one.

Regarding Gallup polls, I have searched for all questions about the ownership status of a given issue during presidential election years, from 1948 to 1996. In particular, I am interested in questions concerning those issues which, following Petrocik [1996], one would ex ante code as permanently owned by the Republican or the Democrats, namely defense and crime on the Republican side, and civil rights, welfare and health care on the Democratic side. When, for a given year, the ownership question about an issue was asked more than once (e.g. more than one question about civil rights being administered during the same presidential year, or about different facets of the same issue), I average the issue ownership percentage, in order to obtain a synthetic measure ${ }^{9}$.

Regarding the civil rights and the welfare issues, Table 1 broadly confirms Petrocik's claim about a permanent Democratic ownership thereof, albeit with some qualifications.

As discussed by Carmines and Stimson [1990], a more precise stance of the Democratic party on the race issue emerged during the late 50s, and consolidated during the early 60s; this was mainly due to the increasingly weak bargaining position of the Southern Democrats within their party. The first column of Table 1 shows that in 1956 and 1960 there was a tiny Democratic advantage on the owner-

\footnotetext{
${ }^{7}$ By issue ownership percentages I am referring to the percentage of respondents believing that a Democrat is better able of handling a given issue, minus the percentage trusting a Republican more.

${ }^{8}$ In the NES, the questions about the most important problem and the ownership status of that problem are respectively coded as VCF0875 and VCF9012.

${ }^{9}$ As Table A.1 and A.2 show, the yearly frequency with which Gallup asked questions about the ownership status of isuues is definitely increasing across time, exponentially so during the late $80 \mathrm{~s}$ and the $90 \mathrm{~s}$.
} 
ship of civil rights, which exploded in 1964, with a lead of almost 35 percent. Since then, the Democrats have maintained an advantage of at least 10 percent on the issue.

Data concerning the welfare issue, i.e. about which party would be better at "helping the poor and the needy", cover a shorter time span, starting from 1972. Here there is a sizeable and permanent perceived advantage for the Democrats, which shows much less time variation than for the race issue, during the same period. Unluckily, pieces of information about the issue of health care are available only for 1992 and 1996 (Gallup), with a Democrats' advantage being above 20 percent.

On the other hand, the pieces of information I have gathered provide a more complex picture of the "Republican" issues of domestic and international security.

Regarding the crime issue, I obtain ownership percentages for seven presidential elections, from 1972 to 1996: in 1972, 1980, 1984 and 1988 there is a Republican advantage, which reaches its peak in 1984, with a lead of almost 39 percent. In 1976, 1992 and 1996 there is in fact a reversal, with a clear Democratic advantage. Just because during three presidential years over a sample of seven there is a Democratic lead, it is not entirely clear whether one can safely code the crime issue as a Republican one ${ }^{10}$.

Finally, the issue of defense and foreign policy, which is covered by the longest stream of Gallup surveys, clearly shows a pattern of Republican ownership. In fact, in nine out of twelve cases there is a GOP lead, with a minimum of less than one percent in 1948 and a peak of more than 44 percent in 1992. The three exceptions occur in 1964, 1980 and 1996. In 1964 Gallup posed two survey questions about the handling of the Vietnam war ${ }^{11}$, and respondents largely attributed a primacy to Johnson's party, with a difference of almost 42 percent. In 1980 ten questions about foreign policy and defense were asked, with two concerning the Iran situation. A problem with these polls is that the most recent ones were administered in the early days of September, so that the final part of the hostage crisis in Iran did not receive any coverage by Gallup. In 1996 there was a clear advantage of Bill Clinton over Bob Dole on the issue. One should however notice how in that year Clinton enjoyed an ownership advantage over Dole on almost all issues.

\subsection{The New York Times dataset}

Data about the coverage of issues by the New York Times is taken from the Policy Agendas Project ${ }^{12}$.

Together with data about Congressional Hearings, Public Laws and Executive

\footnotetext{
${ }^{10}$ One should also bear in mind that the crime issue is the one for which I most frequently use the NES as an ancillary source of information.

${ }^{11}$ See Table A.1 for the specific questions being asked.

${ }^{12}$ See the Project's website at http://www.policyagendas.org. The data used here were originally collected by Frank R. Baumgartner and Bryan D. Jones, with the support of National Science Foundation grant number SBR 9320922, and were distributed through the Center for American Politics and Public Policy at the University of Washington and/or the Department of Political Science at Penn State University. Neither NSF nor the original collectors of the data bear any responsibility for the analysis reported here.
} 
Orders, the Project features a random sample of stories from the New York Times Index, from 1946 to 1997, for a total of 38,470 stories. Each story is classified according to the major topic being addressed, among a set of 27 topics. Apart from this, the dataset provides additional pieces of information about the position of the story on the newspaper (on the front page or in internal pages), and its geographical and institutional relevance.

In particular, stories are classified according to whether they deal with local events, i.e. those occurring in New York City or in the so called TriState area (Connecticut, New Jersey and New York), or not. Moreover, each piece of news is coded according to whether it features domestic events, foreign events with US involvement, or foreign events without US involvement. Finally, stories are classified according to whether they mention actions by some tier of the U.S. government.

While in the original dataset the unit of observation is the single story, I construct monthly counts of stories about the different topics. I also interacted the major topic of the story with its various geographical, institutional and positional features I have mentioned above, in order to obtain more specific time series for each given topic.

In Table 2, I present some descriptive figures about the relative frequencies of issues covered by the New York Times in its articles. For reference, I report the name and the identification number of the topic, as coded in the original dataset by Baumgartner and Jones. Topics are ordered according to the relative frequency of stories (column [1]). Column [2] displays the relative frequency of stories regarding NYC and dealing with the different issues. Column [3] does the same for TriState stories, while column [4] refers to stories that do not have a link with either the TriState or NYC.

The most frequent topic for a story in the New York Times is Banking, Finance and Domestic Commerce, with 15 percent of stories. International Affairs rank second, with more than 13 percent of stories, which in fact confirms the common perception of the Times as a newspaper with a clear focus on international events. The third topic is Federal Government Operations ( 8 percent of stories), closely followed by Defense, with more than 7 percent of stories. Some topics are very relevant at the local level, while they are much less so at the federal one: this is the case for stories about State and Local Administration (almost by definition), about Law \& Crime and about Housing.

The last two rows of Table 2 report the relative frequency of stories about those aggregates of topics which, in accord with the issue ownership dataset, I classify as Democratic and Republican ones ${ }^{13}$. The set of Democratic issues comprises Civil Rights, Health Care, Labor \& Employment and Social Welfare; the set of Republican ones comprises Defense and Law \& Crime. As discussed above, the ownership of the Crime issue by the GOP is not without dispute.

More than 8 percent of all stories are about Democratic topics, while the corresponding figure for Republican ones rises to more than 13 percent. The relative advantage of Republican issues over Democratic ones on the pages of the New York Times is around 6 percent for New York City stories, and around 5 percent for federal ones; it is less than one percent for TriState stories.

\footnotetext{
${ }^{13}$ See section 4.4 below.
} 
The primacy of Banking \& Finance as the most frequently covered topic on the Times could be due to the fact that there is a large number of short stories about the stock market, which are picked up by the random sampling. In fact, when one looks at the front page, a different pattern emerges, as shown by Table 3. The most covered topic on the front page is International Affairs (18 percent of stories). Federal Government Operations and Defense follow, with slightly more than 15 percent of stories each. It turns out that Banking and Finance stories constitute only 3.8 percent of the total stories on the front page, compared with almost 16 percent on internal pages.

Coming back to the comparison between Democratic and Republican issues, the last two rows of Table 3 indeed show that the relative advantage of stories about Republican topics over Democratic ones, being less than 5 percent on internal pages, jumps to more than 11 percent on the front page.

\subsection{The Executive Orders dataset}

The Policy Agendas Project features all Executive Orders enacted by Presidents of the United States, from 1945 to 2001. As mentioned in the introduction, I use this dataset in order to proxy for the activity of incumbent Presidents across issues.

Executive Orders are classified according to their major topic, within a set of 19 issues. There are in fact eight topics less in the Executive Orders dataset than in the New York Times one.

In Table 4 I report some summary statistics about the relative frequency of Executive Orders dealing with the various issues. Topics have been ordered according to their frequency (column [1]), in a descending fashion. The most frequent topic is Federal Government Operations, with more than 23 percent of all Executive Orders: it comprises acts of organisation of the Executive, presidential appointments, and the like. Defense is the second topic by relative frequency, with around 21 percent of all orders, while International Affairs is the third one, with 11 percent.

As in the previous tables about the Times, the last two rows of Table 4 display the relative frequency of Executive Orders concerning Democratic and Republican issues.

In columns [2] and [3] I report the relative frequency of Executive Orders dealing with the various issues, conditionally on the political affiliation of the incumbent President. Some sizeable differences are apparent: for example, there are almost 26 percent Executive Orders about Federal Government Operations under a Republican incumbent, while the corresponding figure is 21.5 percent for Democratic incumbents. Under a Democratic incumbent almost 12 percent of orders concern Labor \& Employment and around 5 percent concern Civil Rights; the corresponding numbers for Republican incumbents amount to 7 and 3 percent respectively. On the other hand, around 3 percent of Executive Orders are about Macroeconomics and Banking \& Finance, while the corresponding figures under a Democratic incumbent do not reach 2 percent.

Given the conditional behaviour of Executive Orders about Civil Rights and Labor \& Employment, which is matched by a similar behaviour of Health Care Or- 
$\operatorname{ders}^{14}$, there are more than 18 percent Executive Orders about Democratic Topics when the incumbent President is a Democrat, as compared to 12 percent under a Republican one. On the other hand, the share of Executive Orders about Republican topics is quantitatively similar for both Republican and Democratic presidents (22 and 23 percent respectively)

\section{Empirical strategy}

\subsection{Identifying assumptions}

In order to analyze the political behaviour of the New York Times, I focus on the time series variation in the choice of issues being addressed in its articles.

In a presidential system like the U.S. one, almost by definition presidential elections play the most crucial role. Thus, the presidential campaign is the period during which the agenda setting power of a newspaper is most valuable, just because it is likely that voters make up their mind about whether and whom to vote as President immediately before the elections, i.e. during the campaign period.

The empirical analysis performed here and the interpretation of its findings are based on the following set of identifying assumptions:

(1) The issue ownership hypothesis holds.

(2) "All publicity is good publicity".

(3) The relative share of Executive Orders about a subset of issues proxies the relative intensity of the activity of the incumbent President with respect to those issues.

First of all, the choice per se of the issues a newspaper covers during the presidential campaign has an electoral effect, to the extent that the first two assumptions hold. In other terms, it must be true that the majority of voters reckons candidates belonging to a given political party as better capable of handling problems related to a given issue, than candidates belonging to the rival party. Moreover, an increased amount of stories about this issue has the predicted effect of favoring the political party owning it, if the stories being published are never too negative about the relative performance on the issue itself of the political party in question.

Given some change in the issue balance of stories the New York Times publishes during the presidential campaign, such change can be attributed to the strategic choice of the newspaper itself if no other political actor is changing its behaviour of news creation along the same time pattern. The prime suspect from such perspective is of course the incumbent President.

Assumption (3) tackles this point, by stating that the relative frequency of Executive Orders concerning a given set of issues enacted by the incumbent President at time $t$ should proxy for the share of time and effort his administration devotes to those issues.

\footnotetext{
${ }^{14}$ Executive Orders about Social Welfare in fact follow an opposite pattern, but this effect is not strong enough to cancel out -within the aggregate of Democratic topics- the pattern found for the other three topics.
} 


\subsection{Some definitions}

As it is implicit in the preceding discussion, there are two main control variables which are relevant for analyzing the political behaviour of a newspaper along the time series dimension.

The first of these variables is the political affiliation of the incumbent President.

Within an issue ownership framework, it is natural to ask whether the newspaper -during non-campaign periods- systematically gives more coverage to issues over which the incumbent President is perceived as strong or weak.

It could be the case that the newspaper is giving more coverage to issues owned by the incumbent President just because it is merely reporting on his level of activity across issues. In order to try and disentangle the presence of a bias by the newspaper, one should therefore control for the intensity of the activity of the incumbent administration towards the various issues. In my empirical specification I use the relative frequency of Executive Orders as a proxy for this relative intensity.

To the extent that the proxy captures the underlying omitted variable, a more intense coverage of issues owned by the incumbent President could be due to various reasons that do not exclude each other.

First, this bias could be due to the fact that the newspaper is acting as a pressure group with respect to these issues, and is taking into account the fact that the incumbent could be more responsive to pressures that regard owned issues.

Alternatively, this bias could be explained witin a political agency framework. If the issue ownership hypothesis holds, citizens would tend to elect a President who is strong on issues that they reckon as salient. Ex post, they want to assess the performance of the elected president on these issues, and therefore demand pieces of information about what the president is delivering during the term. The newspaper responds to this demand for specific information by publishing more stories concerning the issues owned by the incumbent President.

A third explanation has some behavioural flavor. If citizens expect the incumbent President to be more active on owned issues, then they are a priori more interested in stories about these issues. The newspaper accomodates this expectation by publishing more stories about issues owned by the incumbent, as any deviation that goes against the readers' ex ante bias could create a cognitive dissonance effect, which in turn may lower the newspaper's readership and advertising revenue ${ }^{15}$.

Conversely, it could be the case that the newspaper -outside of the electoral campaign- features more stories about the topics over which the incumbent President is weak, still controlling for presidential activity across issues. Such bias could be due to the fact that the newspaper acts as a permanent watchdog with respect to the incumbent President, and concentrates its attention on the issues over which she is perceived as weak by public opinion.

The main focus of this paper is on the electoral behaviour of the New York Times. Indeed, the second control variable which is relevant within a time series framework is the campaign status, i.e. the fact of being under the presidential campaign. A

\footnotetext{
${ }^{15}$ See Mullainathan and Shleifer [2005] for a model of mass media markets, where readers and viewers hold beliefs that they would like to see confirmed.
} 
crucial aspect of the U.S. electoral system is that the date of presidential elections is exogenously fixed: the law commands that they must be held on the first Tuesday following the first Monday of November, every four years. While the end point of the presidential campaign is exogenously fixed by Election Day, the starting point is not exogenous, as it depends on the choices made by the agents involved, i.e. the candidates and the candidates' parties, the mass media and the public. Nonetheless, a typical dictum is that the presidential campaign starts on Labor Day, namely the first Monday in September. Alternatively, one could think about the Convention of the challenger's party as an earlier starting point for the campaign.

My empirical strategy is focused on the comparison between the coverage of electorally relevant topics inside and outside of the presidential campaign.

The mechanism at play here is that the newspaper, by increasing during the presidential campaign period the frequency of articles about issues owned by a given candidate, would induce its readers, at the margin, to go to the ballot and vote for the candidate in question. Given the three identifying assumptions stated above, such increased coverage of owned issues during the presidential campaign would be a symptom of the fact that the newspaper is partisan towards the candidate owning these issues. Moreover, one should check that such increase in the coverage of owned issues does not take place with respect to both Democratic and Republican ones. It is in fact the asymmetry in the increased coverage of Democratic (Republican) issues that is consistent with a corresponding Democratic (Republican) partisanship of the newspaper.

This discussion can be summarised in the following definition:

Definition 1 A newspaper has a Democratic (Republican) partisanship if during the presidential campaign it devotes more space to issues owned by the Democratic (Republican) party, with no increased coverage of Republican (Democratic) issues.

It could be the case that during presidential campaigns the Times behaves differently, as a function of the political affiliation of the incumbent President. In fact, over and above the electoral partisanship of the newspaper, as described by Definition 1 , the effects of the political affiliation of the incumbent President on issue coverage could be given an interpretation within a lapdog/watchdog dichotomy. The idea is the following: if it turns out that -during the presidential campaign- the New York Times gives less emphasis to Democratic topics and/or more emphasis to Republican topics when the incumbent is a Democrat, over and above its Democratic or Republican partisanship, this is consistent with the fact that the newsaper acts as an electoral watchdog with respect to the incumbent President. This is so because the newspaper differentially focuses the attention away from topics over which the incumbent President is on average perceived as strong, towards topics over which he is perceived as weak.

On the contrary, if the newspaper differentially gives more emphasis to Democratic topics and less to Republican ones when the incumbent is a Democrat, the newspaper is said to behave as an electoral lapdog towards the incumbent President. Again, this interaction effect is additive with respect to the partisanship component.

This analysis can be summarised in the following definitions: 
Definition 2 A newspaper is an electoral lapdog of the incumbent President if, ceteris paribus, during the presidential campaign it devotes more space to the issues over which the incumbent is strong, and/or less to issues over which the incumbent is weak.

Definition 3 A newspaper acts as an electoral watchdog if, ceteris paribus, during the presidential campaign it dedicates more space to the issues over which the incumbent is weak, and/or less space to the issues over which the incumbent is strong.

\subsection{A difference in difference approach}

Given the three identifying assumptions stated above and the definitions introduced in the preceding section, the electoral behaviour of the New York Times can be analyzed through a difference in difference approach. In order to illustrate the link between the estimated coefficients and the definitions given in the previous section, I will use a simple linear specification.

Let $y_{t}^{D E M}$ be the relative frequency of stories about Democratic topics the Times publishes during period $t$. One can write the following difference in difference specification for $y_{t}^{D E M}$ :

$$
\begin{aligned}
y_{t}^{D E M}=\beta_{0}+\beta_{1} \mathbf{1}\left(\text { inc }_{t}=D\right)+ & \beta_{2} \mathbf{1}\left(\text { Pcamp }_{t}=1\right) \\
& +\beta_{3} \mathbf{1}\left(\text { inc }_{t}=D \& P c a m p_{t}=1\right)+\delta z_{t}^{D E M}+\varepsilon_{t}
\end{aligned}
$$

where $\mathbf{1}\left(\right.$ inc $\left._{t}=D\right)$ is a dummy that equals one when the incumbent President at time $t$ is a Democrat, $\mathbf{1}\left(\right.$ Pcamp $\left._{t}=1\right)$ is a dummy that equals one during the presidential campaign period ${ }^{16}$, and the third dummy represents the interaction term, i.e. it equals one when there is a presidential campaign and the incumbent President is a Democrat; finally $z_{t}^{D E M}$ stands for the relative frequency of Executive Orders concerning Democratic topics enacted by the incumbent President at time $t$, and $\varepsilon_{t}$ is the error term.

In a specular fashion, one can write the following linear equation for $y_{t}^{R E P}$, the relative frequency of stories about Republican topics published by the Times during period $t$ :

$$
\begin{aligned}
y_{t}^{R E P}=\gamma_{0}+\gamma_{1} \mathbf{1}\left(\text { inc }_{t}=R\right)+ & \gamma_{2} \mathbf{1}\left(\text { Pcamp }_{t}=1\right) \\
& +\gamma_{3} \mathbf{1}\left(\text { inc }_{t}=R \& P_{c a m p}=1\right)+\zeta z_{t}^{R E P}+\eta_{t}
\end{aligned}
$$

where $\mathbf{1}\left(\right.$ inc $\left.P_{t}=R\right)$ is a dummy for the incumbent President being a Republican, $\mathbf{1}\left(\right.$ Pcamp $\left._{t}=1\right)$ is defined as above, and the third dummy represents the interaction between the presidential campaign and the incumbent President being a Republican;

\footnotetext{
${ }^{16}$ Across all specifications presented in section 5, the presidential campaign dummy equals one for the months of August, September and October immediately before the presidential elections.
} 
$z_{t}^{R E P}$ is the relative frequency of executive orders about Republican topics enacted by the incumbent President during the time period, while $\eta_{t}$ is the error term.

The coefficient $\beta_{1}$ on the first dummy in equation (1) refers to the newspaper's behaviour on Democratic stories during the term, as a function of the political colour of the incumbent President. If $\beta_{1}$ turns out to be statistically different from zero and positive, this is consistent with the newspaper finding it worthwhile to emphasize Democratic issues when the incumbent President is a Democrat, even after controlling for the pattern of Executive Orders. On the contrary, if $\beta_{1}$ happens to be negative, this is consistent with the fact that the newspaper is acting as a permanent watchdog with respect to the incumbent. A parallel reasoning can be applied to the coefficient $\gamma_{1}$ in equation (2).

The partisan behaviour of the New York Times, as characterised by Definition 1, can be disentangled by looking at the two coefficients $\beta_{2}$ and $\gamma_{2}$ : if $\beta_{2}$ is statistically different from zero and positive, while $\gamma_{2}$ is not statistically different from zero or negative, this is consistent with the newspaper having a Democratic partisanship. Conversely, if $\gamma_{2}$ is statistically significant and positive, while $\beta_{2}$ is indistinguishable from zero or negative, this is a symptom of the fact that the newspaper has a Republican partisanship.

The interaction terms are meant to capture the differential behaviour of the newspaper during the presidential campaign, as a function of the political color of the incumbent President. If $\beta_{3}$ is positive and statistically significant, this is consistent with the fact that on Democratic topics the New York Times is captured by the incumbent President during the presidential campaign, i.e. it acts as an electoral lapdog. Conversely, if $\beta_{3}$ is found to be negative and significant, this is consistent with the newspaper acting as an electoral watchdog of the incumbent President during the presidential campaign, on Democratic issues. Again in a specular fashion, $\gamma_{3}$ represents the electoral lapdog or watchdog behaviour of the New York Times on Republican topics. In fact, if $\gamma_{3}$ is found to be statistically significant and negative (positive), this is consistent with the New York Times acting as an electoral watchdog (lapdog) of the incumbent President on Republican topics.

A pair of difference in difference tables can further clarify the interpretation of the coefficients:

\begin{tabular}{|l|l|l|l|}
\hline Democratic topics & campaign & no campaign & simple difference \\
\hline Democratic President & $y_{D c}^{D}=\beta_{0}+\beta_{1}+\beta_{2}+\beta_{3}$ & $y_{D n}^{D}=\beta_{0}+\beta_{1}$ & $\Delta y_{D}^{D}=\beta_{2}+\beta_{3}$ \\
\hline Republican President & $y_{R c}^{D}=\beta_{0}+\beta_{2}$ & $y_{R n}^{D}=\beta_{0}$ & $\Delta y_{R}^{D}=\beta_{2}$ \\
\hline simple difference & $y_{D c}^{D}-y_{R c}^{D}=\beta_{1}+\beta_{3}$ & $y_{D n}^{D}-y_{R n}^{D}=\beta_{1}$ & $\Delta y_{D}^{D}-\Delta y_{R}^{D}=\beta_{3}$ \\
\hline
\end{tabular}

\begin{tabular}{|l|l|l|l|}
\hline Republican topics & campaign & no campaign & simple difference \\
\hline Republican President & $y_{R c}^{R}=\gamma_{0}+\gamma_{1}+\gamma_{2}+\gamma_{3}$ & $y_{R n}^{R}=\gamma_{0}+\gamma_{1}$ & $\Delta y_{R}^{R}=\gamma_{2}+\gamma_{3}$ \\
\hline Democratic President & $y_{D c}^{R}=\gamma_{0}+\gamma_{2}$ & $y_{D n}^{R}=\gamma_{0}$ & $\Delta y_{D}^{R}=\gamma_{2}$ \\
\hline simple difference & $y_{D c}^{R}-y_{R c}^{R}=\gamma_{1}+\gamma_{3}$ & $y_{D n}^{R}-y_{R n}^{R}=\gamma_{1}$ & $\Delta y_{D}^{R}-\Delta y_{R}^{R}=\gamma_{3}$ \\
\hline
\end{tabular}

where the part concerning Executive Orders has been omitted for the sake of clarity. The estimated $\beta_{2}$ and $\gamma_{2}$ coefficients can be directly read through Definition 
1. On the other hand, the differential behaviour of the New York Times during the presidential campaign as a function of the political affiliation of the incumbent President is captured by $\beta_{3}$ and $\gamma_{3}$.

The $\beta_{1}$ and $\gamma_{1}$ coefficients stand for the differential behaviour of the New York Times out of the presidential campaign, as a function of the political affiliation of the incumbent President, on Democratic and Republican issues respectively.

\subsection{Democratic vs Republican topics}

Within the set of topics coded by Baumgartner and Jones in the New York Times dataset, I classify the following issues as being owned by the Democrats:

1. Civil Rights

2. Health Care

3. Labor and Employment

4. Social Welfare

For every month, I count the total number of stories about these four topics; this aggregate count represents the number of stories about Democratic topics. Broadly following the survey evidence on issue ownership, I consider Law \& Crime and Defense as Republican issues, but I study them separately in the econometric analysis proper, just because only the latter can be considered as a firm Republican issue, while there is non negligible variation in the ownership status of the former, as witnessed by Gallup and NES polls.

Apart from the unconditional, monthly count of stories about Democratic topics, Defense and Law \& Crime, I also interact the topic with various characteristics of the stories themselves, as classified by Baumgartner and Jones. In the case of stories about Democratic topics and Law \& Crime, I consider domestic ones, stories that deal with New York City, stories regarding the TriState, non-local stories (i.e. those that do not deal with NYC or the TriState), front page ones and stories not on the front page. On the other hand, in the case of Defense stories I consider the subset of domestic stories, non-domestic ones, front page ones and stories on internal pages.

\subsection{Econometric specification}

In order to analyze the time series behaviour of the Times in the issue space, I use a count data model. As it is standard in the literature (see Cameron and Trivedi [1998] and Wooldridge [2001]), I adopt a Poisson model, with a log-linear specification of the conditional expectation.

Let $x_{t}^{D E M}$ be the count of stories about Democratic issues published by the Times during period $t$. Its conditional expectation can be written as follows:

$$
E\left(x_{t}^{D E M} \mid \mathbf{z}_{t}^{D E M}\right)=\exp \left[\begin{array}{c}
\beta_{0}+\beta_{1} \mathbf{1}\left(\text { inc }_{t}=D\right)+\beta_{2} \mathbf{1}\left(\text { Pcamp }_{t}=1\right) \\
+\beta_{3} \mathbf{1}\left(\text { inc }_{t}=D \& \text { Pcamp }_{t}=1\right)+\boldsymbol{\delta}^{\prime} \mathbf{w}_{t}^{D E M}
\end{array}\right]
$$


where $\mathbf{w}_{t}^{D E M}$ is a set of controls. Equation (3) corresponds to equation (1), having assumed a log-linear Poisson model.

By the same token, the conditional expectation for $x_{t}^{R E P-d}$, i.e. the count of stories about Defense at time $t$, can be written as:

$$
E\left(x_{t}^{R E P-d} \mid \mathbf{z}_{t}^{R E P-d}\right)=\exp \left[\begin{array}{c}
\gamma_{0}+\gamma_{1} \mathbf{1}\left(\text { inc }_{t}=R\right)+\gamma_{2} \mathbf{1}\left(\text { Pcamp }_{t}=1\right) \\
+\gamma_{3} \mathbf{1}\left(\text { inc }_{t}=R \& \text { Pcamp }_{t}=1\right)+\boldsymbol{\zeta}^{\prime} \mathbf{w}_{t}^{R E P-d}
\end{array}\right]
$$

I adopt the same specification for $x_{t}^{R E P-c}$, namely the count of stories about Law \& Crime.

Regarding control variables, the presidential campaign dummy equals one for the months of August, September and October immediately before the presidential elections. The vectors $\mathbf{w}_{t}^{D E M}, \mathbf{w}_{t}^{R E P-d}$ and $\mathbf{w}_{t}^{R E P-c}$ always include a linear and quadratic time trend, a set of monthly dummies (January is the baseline month), and the total number of stories at time $t$. This last variable should control for the time-varying size of the Times. Moreover, $\mathbf{w}_{t}^{D E M}$ includes the relative frequency of Executive Orders about Democratic issues enacted by the incumbent President during period $t$. The same is true for $\mathbf{w}_{t}^{R E P-d}$ and $\mathbf{w}_{t}^{R E P-c}$. For each sub-category of stories (e.g. domestic stories about Democratic issues) I also control for the total number of stories pertaining to that category that the Times publishes in each period (in the example: total number of domestic stories per month). Given the observed reversals in the ownership status of the Defense and Law \& Crime issues (see section 3.1 above), I include a separate dummy for the presidential campaigns during which such reversals occur. These campaigns are 1964, 1980 and 1996 for Defense, and 1976, 1992 and 1996 for Law \& Crime. Finally, in order to control for the underlying real world events, in the case of Defense stories I include the number (expressed in thousands) of U.S. soldiers killed-in-action (KIA) during the time period ${ }^{17}$.

Standard errors are calculated using the Huber/White sandwich formula, in order to obtain inferences that are robust to non-Poisson heteroskedasticity.

\section{Results}

This section is divided in four parts. In the first part I run the regressions with the baseline specification I have mentioned above. In the second part I add controls regarding the political situation at the local level and the identity of the New York Times publisher. In the third subsection I focus on the more recent time sample, i.e. from 1961 to 1997. In the last subsection I perform some robustness checks.

\subsection{Baseline specification}

The baseline results concerning Democratic topics and the two Republican ones are featured on Table 5, 6 and 7. As mentioned above, the regression on topic $i$ includes as controls the relative frequency of executive orders on that topic enacted at time

\footnotetext{
${ }^{17}$ I thank Douglas Hibbs for kindly providing the KIA data.
} 
$t$, the total number of stories published at time $t$ and appearing in the sample, monthly dummies, and a linear and quadratic trend. In each table, the first column refers to all stories, while the subsequent ones stand for the different subcategories of stories. In the latter case, I also control for the total number of stories pertaining to that subcategory.

For each explanatory variable, the incidence rate ratio ${ }^{18}$ is reported, with robust z-statistics in brackets.

The main message stemming from the joint examination of these tables is that the New York Times systematically publishes more stories about Democratic topics during presidential campaigns, but only so when the incumbent president is a Republican. In fact, regarding the Republican issues of Defense and Law \& Crime, there is no systematic variation in the coverage during presidential campaigns. The only exception is represented by front page stories. The Times publishes less front page articles about Defense during the presidential campaign, when the incumbent President is a Republican. On the other hand, there are more front page stories about Law \& Crime during the presidential campaign, when the incumbent president is a Republican.

Apart from this latter result on front page stories about Crime, the overall pattern is consistent with the New York Times showing a Democratic partisanship, with some watchdog aspects, in that there is an increase in the count of stories about Democratic topics during the presidential campaign, which occurs only when the incumbent President is perceived as weak on these issues, i.e. he is a Republican.

In particular, when the incumbent President is a Republican, there are on average around 26.6 percent more stories about Democratic topics as the presidential campaign kicks in (Table 5, column [1]). When significant, the magnitude of the effect is comparable across different subsets of stories, apart from NYC ones: in this case, there are more than double the number of stories about Democratic topics during the presidential campaign and under a Republican incumbent. The effect is strongly significant (one percent confidence level) for all stories, NYC ones and those not on the front page. It is significant at 5 percent confidence level for domestic stories.

The interaction term is always estimated to be negative across all subcategories of news (incidence rate ratios below one), and it is significantly different from zero at ordinary confidence levels for all stories (10 percent) and domestic ones ( 5 percent). In any case, one can never reject the hypothesis that the presidential campaign does not produce any change in the count of stories about Democratic topics when the incumbent President is a Democrat. This is shown by the p-value on the corresponding t-test, which is reported below the coefficients under each column in Table 5.

Regarding the effects of the political affiliation of the incumbent President on Democratic stories, a consistent pattern emerges: during the term there are system-

\footnotetext{
${ }^{18}$ The incidence rate ratio represents the relative change in the dependent variable which is associated with a unitary change of the explanatory variable. In the case of a dummy variable, an incidence rate ratio of $1+y$, with $y>0$, stands for the fact that there are on average $y$ percent more successes (in my case: stories) when the dummy equals one, as compared to the case when the dummy equals zero.
} 
atically more stories about Democratic topics when the President is a Democrat, even after controlling for presidential activity, as proxied by the relative frequency of Executive Orders. There are on average around 18 percent more stories about Democratic topics under a Democratic incumbent (Table 5, column [1]). The magnitude of such an effect is comparable for domestic stories, non-local stories and stories not on the front page, while it is larger (more than 27 percent) for front page ones. This larger coverage of Democratic topics during the term when the President is a Democrat helps understand the results concerning the Times behaviour during the presidential campaign: when the incumbent is a Democrat the aggregate aggregate count of stories about Democratic topics is already high outside the presidential campaign, and the presidential campaign does not produce any additional effect.

The fourth row in the table displays the effect of the relative share of Executive Orders. In only one cases out of seven is the incidence rate ratio larger than one, indicating a positive correlation between the share of Executive Orders about Democratic topics and the count of stories on the Times. However, this effect is not statistically significant. The same holds true for the six cases in which the point estimate of the incidence rate ratio is less than one.

Finally, it turns out that the larger is the newspaper (as proxied by the total number of stories being sampled each month), the higher is the count of stories about Democratic topics (column [1]): this is a scale effect, which is very precisely estimated. When considering the various subcategories of articles, it turns out that the size of the newspaper is no longer significantly correlated with the count of stories about Democratic topics, while this is the case for the total number of stories in each subcategory.

Table 6 shows estimation results for the Defense issue. The presidential campaign dummy and the interaction are never significantly correlated with the count of stories about Defense (incidence rate ratios are indistinguishable from one). This is also the case for the ownership-reversal dummy, which -as said above- equals one for the 1964, 1980 and 1996 campaigns. However, it turns out that there are systematically less Defense stories on the front page during the presidential campaign, when the incumbent President is a Republican. This is witnessed by the fact that the $\mathrm{p}$-value on the corresponding t-test is around 0.05 , thus rejecting the null hypothesis of no effects of the presidential campaign under a Republican incumbent.

In a parallel fashion to what found for stories about Democratic issues, it turns out that there are systematically more stories about Defense when the incumbent President is a Republican. This correlation is significant at ordinary confidence level for all categories of news but domestic ones. The point estimates imply that there are around 10 percent more articles about Defense under a Republican incumbent than a Democrat, if one considers all stories, non-domestic ones and stories on internal pages. Such increase amounts to 20 percent in the case of front page stories.

Moreover, one should notice that the correlation between Defense stories and Executive Orders is always estimated to be positive, but is larger in magnitude and statistically significant only for domestic stories. On the other hand, the number of killed in action (KIA) is a strongly significant and positive predictor of Defense 
stories, for all categories of news.

Regarding Law \& Crime stories (see Table 7), the coefficients on the presidential campaign dummy and the interaction are never significantly different from zero (incidence rate ratios different from one). This holds for the ownership-reversal dummy as well. In fact, when the incumbent President is a Republican, there are significantly more front page articles about Law \& Crime as the presidential campaign kicks in. In particular, one can reject the null hypothesis of no effects of the presidential campaign under a Republican incumbent.

Finally, the correlation between Law \& Crime articles and Executive Orders is always estimated to be positive, but it is statistically significant only for the subset of domestic stories.

\subsection{Additional controls: New York State Governor, New York City Mayor and publisher's identity}

As discussed in section 3.2, the New York Times can be considered the main newspaper for the city of New York, and for the states of New York, Connecticut and New Jersey (the TriState area). Hence, one would like to check whether the results obtained in the preceding section are robust to the inclusion of controls related to the political situation in New York City and in the State of New York, which is the most important one within the TriState area. In particular, the idea is to control for the political affiliation of the incumbent Governor of New York State, and of the incumbent New York City Mayor.

Secondly, the ownership structure of the Times could have effects on the equilibrium supply of stories. The New York Times was founded in 1851 by Henry J. Raymond and George Jones, and in 1896 was bought by Adolph S. Ochs. Since then, the Ochs-Sulzberger family has continuously kept the ownership of the newspaper. However, in the time span that is covered by the dataset, four different members of the Ochs Sulzberger family have played the role of publisher: Arthur Hays Sulzberger, son-in-law of Adolph S. Ochs, from April 1935 to April 1961, Orvil Dryfoos, son-in-law of Arthur Hays Sulzberger, from May 1961 to May 1963, Arthur Ochs Sulzberger, from June 1963 to January 1992, and finally Arthur Sulzberger Jr., son of Arthur Ochs Sulzberger, from February 1992 to nowadays.

In Table 8 the monthly count of stories about Democratic topics is regressed against the set of variables being used in Tables 5, plus five additional dummies, that control for the political affiliation of the incumbent NYS Governor, of the incumbent NYC Mayor, and the publisher's identity. The NYS Governor dummy equals one when the incumbent is a Democrat, and zero otherwise. The same applies to the NYC Mayor dummy ${ }^{19}$. Regarding the publisher's identity, I use three different dummies for the last three publishers, and leave Arthur Hays Sulzberger as the baseline publisher.

Tables 9 and 10 display results for the count of stories about Defense and Law \& Crime, respectively. Here the dummy variables for the political affiliation of the

\footnotetext{
${ }^{19}$ Vincent R. Impellitteri was Mayor of New York City from 1950 to 1953, and was in fact elected as an Independent. However, given his lifelong affiliation to the Democratic Party, I have coded him as a Democrat.
} 
incumbent NYS Governor and NYC Mayor equal one for a Republican incumbent.

The joint inspection of these three tables confirms the findings obtained with the baseline specification. There are systematically more stories about Democratic topics during the presidential campaign, but less so when the incumbent President is a Democrat. In fact, one still cannot reject at ordinary confidence levels the null hypothesis of no effects of the presidential campaign under a Democratic incumbent. The size and level of significance of the coefficients on the presidential campaign dummy and the interaction are very similar to those found under the baseline specification.

On the other hand, some discrepancies emerge when looking at the partial correlation with the political affiliation of the incumbent President. It is still the case that -during the term- there are more stories about Democratic issues when the President happens to be a Democrat, but the size of the coefficient and the significance level are smaller than the ones obtained with the baseline specification. The point estimate for all stories and domestic ones implies a 10 percent increase in the coverage of Democratic topics when the incumbent President is a Democrat, which should be compared with a 18 percent increase in the baseline regression. The only exception to this pattern of decreased size and significance occurs with TriState stories: when controlling for the political affiliation of the NYS Governor and NYC mayor, there are on average around 39 percent more Democratic stories under the presidency of a Democrat. This is coupled with a 77 percent increase in the coverage of TriState stories about Democratic issues, when the incumbent NYS Governor is a Democrat (Table 8, column [4]). Both partial correlations are strongly significant. Moreover, if one considers all stories, there are 10 percent more articles about Democratic issues when the incumbent NYS Governor is a Democrat.

The correlation of Democratic stories with the political colour of the incumbent NYC Mayor shows an opposite pattern: there are significantly less articles about Democratic issues under a Democratic NYC Mayor, i.e. the Times appears to act as a permanent watchdog towards Republican NYC Mayors.

Finally, there are systematically more stories about Democratic topics under the last two publishers, i.e. Arthur Ochs Sulzberger and Arthur Sulzberger Junior. The effect is large and precisely estimated for all stories, domestic and non-local ones.

Regarding Defense stories, there are no significant effects of the presidential campaign and of the campaign interacted with the political affiliation of the incumbent President. Again, the only exception occurs with front page stories. There are systematically less Defense stories on the front page during the presidential campaign, when the incumbent President is a Republican, as shown by the p-value on the corresponding t-test (Table 9, column [4]).

Similarly to what found with the baseline specification, there are significantly more stories about Defense when the incumbent President is a Republican. The coefficient is now larger and more precisely estimated, with the exception of front page stories. In particular, if one considers all stories (column [1]) there are around 27 percent more Defense stories under the Presidency of a Republican. On the other hand, there is no significant correlation between Defense stories and the political affiliation of the NYS Governor, while there systematically more Defense articles when the incumbent NYC Mayor is a Republican. Regarding the publishers' effects, 
the second and the third publisher are associated with significantly more stories about Defense.

Coming to the Law \& Crime issue, Table 10 shows that the presidential campaign dummy and the interaction term between the campaign and the political affiliation of the President are not significantly correlated with the count of stories about the topic, for all categories of news. This is also the case for the ownership-reversal dummy. As with the baseline specification, there are more front page stories about Law and Crime during the campaign when the incumbent President is a Republican.

Finally, there is some positive and significant correlation between Law \& Crime stories and the incumbent NYC Mayor being a Republican (for all stories, domestic and TriState ones), and the same is true for the last two publishers.

\subsection{The New York Times' behaviour as of the 60s}

The purpose of this section is to investigate the editorial choices of the Times in more recent years, namely from 1961 to 1997. A closer look to the behaviour of the New York Times as of the 60s is motivated by the availability of more detailed pieces of information about issue ownership. Moreover, as illustrated in section 3.1, the issue of Civil Rights clearly emerges as a Democratic one only with the Kennedy and Johnson presidency.

In the present exercise I control for the same set of additional variables I have used in the previous section, i.e. the political affiliation of the incumbent NYS Governor and NYC Mayor, and the publisher's identity.

Table 11 displays results about Democratic stories. The overall pattern of findings quite closely corresponds to the ones obtained with the previous specification. During the presidential campaign there are more stories about Democratic topics, but only so when the incumbent President is a Republican. The magnitude of the effect is in fact larger during the more recent time span. If one considers all stories, the Times publishes around 33 percent more Democratic stories during the campaign under a Republican incumbent, and 27 percent more in the case of domestic stories. Regarding NYC stories, the increase in the coverage of Democratic topics during the presidential campaign is more than threefold. In the post-1960 period, there is also a statistically significant increase in the count of front page stories about Democratic issues. The size of the effect is large, with a more than twofold increase. The interaction term between the presidential campaign dummy and the political affiliation of the incumbent President is significant at the 5 percent level for domestic stories and NYC ones.

Outside of the presidential campaign, again there are more stories about Democratic issues under the presidency of a Democrat. If one considers all stories, there are on average around 13 percent more Democratic stories under a Democratic President. In the post-1960 subsample there is a larger and more significant positive correlation between the count of stories about Democratic topics and the incumbent NYS Governor being a Democrat. In particular, there are around twice the number of TriState stories under a Democratic NYS Governor, and almost three times the number of front page stories. The negative correlation between Democratic stories and the incumbent NYC Mayor being a Democrat is confirmed in the more recent 
subsample, as the positive correlation with the last two publishers.

Regarding stories about Defense, Table 12 shows a pattern of results that is quite different from the one found when analysing the entire time sample. When the incumbent President is a Democrat and there is no reversal in the ownership of the issue, the Times systematically publishes more stories about Defense, as the presidential campaign starts. Such result should be taken with some caution, just because -in the post-1960 period- the only presidential year under a Democratic incumbent during which there is no reversal in the ownership of the Defense issue is 1968 , i.e. in the middle of the Vietnam War.

The effect of the 1968 campaign is strongly significant (one percent confidence level) and large in magnitude for all stories, domestic ones and those not on the front page. The correlation is smaller and slightly less significant for non-domestic stories. On the other hand, the coefficient on the ownership reversal dummy, when significantly different from zero (as it is the case for domestic stories and those on internal pages), is estimated to be negative.

The coefficient on the interaction between the presidential campaign and the incumbent President being a Republican is estimated to be negative (incidence rate ratios less than one) and significantly so for all categories of stories but front page ones. In particular, for all stories and front page ones one can reject at the 10 percent level the null hypothesis that the Times does not change the coverage of Defense stories during the presidential campaign under a Republican incumbent. The joint inspection of the incidence rate ratios suggests that there is indeed a decrease in the count of all stories and front page ones about Defense. Below the p-values on the test about the effect of the campaign under a Republican President, I report the p-values of a similar test on whether there is a change in the count of Defense stories during the presidential campaigns that are characterised by a reversal in the ownership of the issue. At ordinary confidence levels one can never reject the null hypothesis of no effects.

Finally it must be noticed that outside of the presidential campaign there are systematically more Defense stories when the incumbent President is a Republican, around 50 percent. The correlation is very precisely estimated (one percent confidence level) for all but front page stories. Overall, the set of estimated coefficient is consistent with a watchdog attitude of the Times during the presidential campaign, as there are more Defense stories during the 1968 campaign, while there is a decrease in such count during the campaign when the incumbent President is perceived as more competent on the issue, i.e. he is a Republican. Moreover, in those campaign years that are characterised by a reversal in the ownership of the issue, the Times is marginally less inclined to publish stories about it.

Table 13 presents results about Law \& Crime stories. As with the entire time sample, there are no remarkable movements in count of stories about the issue during presidential campaigns. Similarly to what found in Table 10, when the incumbent President is a Republican and the presidential campaign starts there are significantly more front page stories about Law \& Crime. This is also the case for TriState stories. Differently from previous results, there are systematically more non-local stories about the issue under the incumbency of a Republican President. Finally, there are more Law \& Crime stories under a Republican NYC Mayor and 
under the last publisher.

\subsection{Robustness checks}

One relevant concern about the validity of these findings is that the autocorrelation of the right hand side variables might excessively deflate the estimated standard errors. In order to address this issue, I have run all regressions on collapsed data ${ }^{20}$. To do so, I calculate the average of all variables for each presidential term and each campaign, so that I am left with 27 observations for the entire sample, and 18 for the post-1960 period. On this collapsed data I have run Poisson regressions, with heteroskedasticity-robust standard errors.

The results obtained in the previous sections are robust to this check. In Table 14 I summarise the results of the exercise on Democratic topics, Defense and Law \& Crime, when the baseline specification (see section 5.1 above) is applied to all stories $^{21}$, both for the entire time sample and the post-1960 period.

Consistently with what done before, the incumbent President dummy equals one under a Democratic President when dealing with Democratic stories (Table 14, columns [1] and [4]), vice versa for Defense and Law \& Crime stories. The interaction term between the presidential campaign dummy and the incumbent President one is defined accordingly.

Regarding Democratic issues, there are systematically more articles about them during the presidential campaign, when the incumbent President is a Republican. The coefficient on the presidential campaign dummy is highly significant for both the entire sample and the more recent period, with one and 5 percent confidence level respectively. The point estimates imply a 22 percent and a 25 percent increase in the coverage of these topics during the campaign, under the incumbency of a Republican President. The coefficients on the interaction term are estimated to be negative (incidence rate ratios less than one), but not significantly $\mathrm{so}^{22}$. Again, in both cases one cannot reject at ordinary confidence level the null hypothesis that the presidential campaign does not produce any change in the count of Democratic stories under a Democratic President.

When considering the entire time sample, Defense stories do not display any systematic change during the presidential campaign (column [2]), as in Table 6 . The coefficient on the ownership reversal dummy is in fact mildly significant at 10 percent level, implying a 45 percent increase in the count of Defense stories during the presidential campaign when such reversal occurs. However, a joint test on the presidential campaign dummy and the ownership reversal one cannot reject the null hypothesis that there is no overall change in the count of Defense stories, during the presidential campaigns that are characterised by such reversal. Apart from this, number of KIA and the relative frequency of Executive Orders are strongly and significantly correlated with the count of Defense articles.

\footnotetext{
${ }^{20}$ See Bertrand et al. [2004] for a full discussion of the issue.

${ }^{21}$ Results on the different subcategories of news are available upon request.

${ }^{22}$ In fact, in the case of domestic stories (not reported in the table) the interaction term is significantly different from zero at one percent confidence level for the entire sample, and at 5 percent for the post-1960 one.
} 
On the other hand, in the post-1960 sample the analysis of the collapsed dataset shows that there are systematically less stories about Defense during the presidential campaign, when the incumbent President is a Republican. The effect is large and very precisely estimated (one percent confidence level). Under a Republican President there are systematically more stories about Defense. The magnitude and significance of these two effects correspond to what found on the original dataset (see section 5.3). This is not the case for the presidential campaign dummy, which should account for the 1968 campaign: its coefficient is estimated to be positive (incidence rate ratio larger than one), but is not statistically significant. The same is true for the ownership reversal dummy.

Finally, stories about Law \& Crime display the same (absence of) pattern that has been discussed in the previous sections. However, if one considers the entire time sample (column [3]), it turns out that there more stories about the topic during the presidential campaign when the incumbent President is a Republican. The effect is mildly significant at the 10 percent confidence level.

\section{Discussion and conclusions}

This paper provides new evidence about the political behaviour of the New York Times, by analysing the time series variation in the count of stories about politically relevant topics. The main finding is that the Times displays a Democratic partisanship, with some watchdog aspects. This is the case, because there are systematically more stories about Civil Rights, Health Care, Labour and Social Welfare during the presidential campaign, but only so when the incumbent President is a Republican. This is true for both the entire sample and the more recent 1961-1997 subperiod.

When looking at the entire 1946-1997 sample, the Democratic partisanship hypothesis finds confirmation in the fact that there is no comparable variation during the presidential campaign in the count of stories about Defense and Law \& Crime, which -as broadly confirmed by the analysis of Gallup Polls and the NES- represent more favorable issues for the GOP.

On the other hand, there are signs of a more symmetric watchdog behaviour of the Times when considering the more recent period, just because the Defense issue is covered more heavily during the presidential campaign when the incumbent President is a Democrat and there is no reversal in the ownership of the issue itself. In fact, when the President is a Republican, there are less Defense stories overall and on the front page as the presidential campaign starts. A caveat here is that the only presidential campaign under a Democratic incumbent with no ownership reversal is the 1968 one, i.e. in the middle of the Vietnam War.

Within the growing empirical literature on mass media bias, the methodology I have applied here to the New York Times has three novel features. First, it is focused on the agenda-setting behaviour of the newspaper, i.e. on its issue coverage. Such agenda-setting framework, coupled with the issue ownership hypothesis, provides a natural way to think about the political stance of the newspaper.

Secondly, my empirical analysis crucially exploits the time variation in the issue coverage by the Times, in order to understand how such coverage changes during 
the presidential campaign period. Thirdly, given the sample length, I am able to provide additional evidence about the differential behaviour of the Times during presidential campaigns as a function of the political affiliation of the incumbent President.

How do my findings relate to the theoretical literature on mass media bias? It is clearly the case that the systematic variations in the editorial choices of the Times I have shown to occur during presidential campaigns are consistent with media bias, i.e. with a precise political stance of the newspaper, which emerges outside the editorials' page proper. However, given the structure of the available data, it is hard to test the empirical validity of supply-led stories á la Baron against demanddriven ones, as those suggested by Mullainathan and Shleifer, and Gentzkow and Shapiro. Moreover, one cannot rule out the role played by the political bias of the owner, especially in the case of a newspaper like the Times. This latter argument is corroborated by the fact that some of the changes in the publisher's identity have a systematic impact on the count of stories about Democratic topics and -to a lesser extent- about Law \& Crime.

The idea of a watchdog behaviour by news providers is quite well established within the journalism literature ${ }^{23}$, where it works as a normative benchmark, but it also appears in the political economy one ${ }^{24}$.

In this case too both a supply and a demand-led story would be compatible with the data. Journalists and publishers alike could trade off monetary rewards against the "moral payoff" of acting as watchdogs with respect to the incumbent government. On the other hand, readers and viewers might be exactly demanding a more intense coverage of issues over which there is more uncertainty regarding the incumbent's performance. It could also be the case that consumers of news hold a priori beliefs about what policy areas are more likely to be characterised by a poor performance by the incumbent. A desire to see news providers confirming these beliefs, or a Bayesian inclination to attach a higher expectation of quality reporting to those that do so could contribute to explaining what I denote as a watchdog behaviour during presidential campaigns.

Apart from devising an empirical strategy that can disentangle these different theories of media bias, much work remains to be done. On the intensive side, one would like to go beyond an identification strategy that is based on agenda setting, and instead try and classify the way issues are framed by the media. A problem with this strategy is in fact the one of inter-coder reliability, which is much less severe in the case of agenda-setting proper. On the extensive side, one could apply the present methodology to other mass media outlets, in particular to a panel of them. The idea is to estimate the fixed effects of their position in the political spectrum, by looking at the average balance of stories about conservative and liberal topics, over and above the study of their time series behaviour.

\footnotetext{
${ }^{23}$ See for example Bennett and Serrin [2005].

${ }^{24}$ Such concept of "media as watchdogs" is central in the Downsian setup of Chan and Suen [2003] and it is largely implicit in the political agency framework of Besley and Burgess [2002] and Besley and Prat [2005].
} 


\section{References}

[1] Ansolabehere, S. D. and Iyengar, S. [1994]. "Riding the Wave and Claiming Ownership over Issues: the Joint Effects of Advertising and News Coverage in Campaigns". Public Opinion Quarterly, 58(3): 335-357.

[2] Ansolabehere, S., Lessem, R. and Snyder, J. M. Jr. [2004]. "The Political Orientation of Newspaper Endorsements in U.S. Elections". mimeo, MIT.

[3] Baron, D. P. [2006]. "Persistent Media Bias". Journal of Public Economics, 90(1): 1-36.

[4] Behr, R. L. and Iyengar, S. [1985]. "Television News, Real-World Cues, and Changes in the Public Agenda". Public Opinion Quarterly, 49(1): 38-57.

[5] Bennett, W. L. and Serrin, W. [2005]. "The Watchdog Role" in Overholser G. and Jamieson, K. H., eds., The Press. New York: Oxford University Press: 169-188.

[6] Benoit, W. L., Hansen, G. J. and Petrocik, J. R. [2003]. "Issue Ownership and Presidential Campaigning". Political Science Quarterly, 118(4): 599-626.

[7] Bertrand, M., Duflo, E. and Mullainathan, S. [2004]. "How Much Should We Trust Difference in Differences Estimates?" Quarterly Journal of Economics, 119(1): 249-275.

[8] Besley, T. and Burgess, R. [2002]. "The Political Economy of Government Responsiveness: Theory and Evidence from India" Quarterly Journal of Economics, 117(4): 1415-1452.

[9] Besley, T. and Prat, A. [2005]. "Handcuffs for the Grabbing Hand? Media Capture and Government Accountability". American Economic Review, forthcoming.

[10] Cameron, A. C., and Trivedi, P. K. [1998]. Regression Analysis of Count Data. Cambridge, Cambridge University Press.

[11] Carmines, E. G. and Stimson, J. A. [1990]. Issue Evolution: Race and the Transformation of American Politics. Princeton, Princeton University Press.

[12] Chan, J. and Suen, W. [2003]. "Media as Watchdogs: The Role of News Media in Electoral Competition", John Hopkins University WP no. 497.

[13] Cohen, B. [1963]. The Press and Foreign Policy. Princeton, Princeton University Press.

[14] DellaVigna, S. and Kaplan, E. [2005]. "The Fox News Effect: Media Bias and Voting", mimeo, UC Berkeley.

[15] Erbring, L., Goldenberg, E. N. and Miller, A. H. [1980]. "Front-Page News and Real-World Cues: A New Look at Agenda-Setting by the Media". American Journal of Political Science, 24(1): 16-49. 
[16] Feeley, T. J. [2001]. "Individual Issue Ownership in Congress, 1981-1996". Paper presented at the 2001 Annual Meeting of the American Political Science Association, San Francisco, California, August-September.

[17] Franken, A. [2003]. Lies and the Lying Liars Who Tell Them: A Fair and Balanced Look at the Right. New York, EP Dutton.

[18] Gentzkow, M. and Shapiro, J. M. [2006] "Media Bias and Reputation". Journal of Political Economy, forthcoming.

[19] Goldberg, B. [2002]. Bias: a CBS Insider Exposes How the Media Distort the News. Washington, Regency Pub.

[20] Groseclose, T. and Milyo, J. [2005]. "A Measure of Media Bias". Quarterly Journal of Economics, 120(4): 1191-1237.

[21] Iyengar, S., Kinder, D. R., and Peters, M. D. [1982]. "Experimental Demonstrations of the "Not-So-Minimal" Consequences of Television News Programs". The American Political Science Review, 76(4): 848-858.

[22] Iyengar, S. and Simon, A. F. [2000]. "New Perspectives and Evidence on Political Communication and Campaign Effects". Annual Review of Psychology 51: $149-169$.

[23] Lippmann, W. [1922]. Public Opinion. New York, Harcourt, Brace.

[24] Lott, J. R., Jr. and Hassett, K. A. [2004]. "Is Newspaper Coverage of Economic Events Politically Biased?" Working Paper, American Enterprise Institute, Washington, DC.

[25] McCombs, M. E. [2002]. "The Agenda-Setting Role of the Mass Media in the Shaping of Public Opinion". Paper presented at Mass Media Economics 2002 conference, London School of Economics: http://sticerd.Ise.ac.uk/dps/extra/McCombs.pdf

[26] McCombs, M. E. and Shaw, D. L. [1972]. "The Agenda-Setting Function of Mass Media". Public Opinion Quarterly, 36(2): 176-187.

[27] Mullainathan, S. and Shleifer, A. [2005]. "The Market for News". American Economic Review, 95(4): 1005-1030.

[28] Petrocik, J. R. [1996]. "Issue Ownership in Presidential Elections, with a 1980 Case Study". American Journal of Political Science, 40(3): 825-850.

[29] Sutter, D. [2001]. "Can the Media Be So Liberal? The Economics of Media Bias". Cato Journal, 20(3): 431-452.

[30] Wooldridge, J. M. [2001]. Econometric Analysis of Cross Section and Panel Data. Boston, MIT Press. 
Table 1: Perceived Issue Handling Competence of Parties, Democrats' advantage

\begin{tabular}{|c|c|c|c|c|c|}
\hline & civil rights & welfare & health care & law \& crime & defense \\
\hline 1948 & . & . & . & . & -0.58 \\
\hline 1952 & . & . & . & . & -24.85 \\
\hline 1956 & 2.42 & . & . & . & . \\
\hline 1960 & 3.46 & . & . & . & -16.24 \\
\hline 1964 & 34.94 & . & . & . & 41.95 \\
\hline 1968 & 11.11 & . & . & $\cdot$ & -14.10 \\
\hline 1972 & 10.94 (NES) & 27.36 (NES) & . & -23.82 & -20.95 \\
\hline 1976 & 16.98 & 30.11 & . & 9.15 (NES) & -14.59 \\
\hline 1980 & 25.55 & 25.08 & . & -15 (NES) & 8.81 \\
\hline 1984 & 29.81 & 34.67 & . & -38.89 (NES) & -8.24 \\
\hline 1988 & 23.26 & 29.40 & . & -9.30 & -5.76 \\
\hline 1992 & 16.76 & 35.30 & 27.88 & 3.94 & -44.32 \\
\hline 1996 & 14.46 & 16.65 & 21.12 & 9.79 & 8.15 \\
\hline
\end{tabular}

Notes: for each issue and each presidential year, I report the difference between the percentage of respondents believing that a Democrat would be better able of handling that issue and the percentage of respondents believing that a Republican would be. When not stated otherwise, the data come from Gallup polls, as detailed in table A.1 and A.2. NES data are presented in table A.3. Issue ownership figures that do not conform with Petrocik [1996] are highlighted. 
Table 2: Relative frequencies of stories on the New York Times (1946-1997), by topic and geographical location

\begin{tabular}{|c|c|c|c|c|}
\hline Major Topic & $\begin{array}{c}{[1]} \\
\text { All stories }\end{array}$ & $\begin{array}{c}{[2]} \\
\text { NYC stories } \\
\end{array}$ & $\begin{array}{c}{[3]} \\
\text { TriState stories } \\
\end{array}$ & $\begin{array}{c}{[4]} \\
\text { Non-local stories } \\
\end{array}$ \\
\hline 15 Banking, Finance and Dom. Commerce & 15.14 & 6.00 & 7.12 & 16.91 \\
\hline 19 International Affairs & 13.10 & 1.29 & 0.41 & 15.64 \\
\hline 20 Federal Government Operations & 8.16 & 1.57 & 3.79 & 9.29 \\
\hline 16 Defense & 7.35 & 1.01 & 1.23 & 8.64 \\
\hline 28 Arts and Entertainment & 6.34 & 5.66 & 2.63 & 6.81 \\
\hline 12 Law, Crime and Family Issues & 5.72 & 15.12 & 11.30 & 4.18 \\
\hline 24 State and Local Government Admin. & 5.21 & 21.13 & 26.77 & 1.31 \\
\hline 99 Other & 4.80 & 4.56 & 2.69 & 5.05 \\
\hline 6 Education & 3.98 & 9.37 & 8.20 & 2.99 \\
\hline 10 Transportation & 3.48 & 6.63 & 5.78 & 2.91 \\
\hline 3 Health & 2.98 & 4.18 & 5.02 & 2.64 \\
\hline 5 Labor \& Employment & 2.68 & 2.96 & 2.89 & 2.63 \\
\hline 17 Space, Science, Technology and Comm. & 2.19 & 0.69 & 0.79 & 2.50 \\
\hline 18 Foreign Trade & 2.13 & 0.13 & 0.26 & 2.54 \\
\hline 8 Energy & 2.01 & 1.16 & 2.07 & 2.09 \\
\hline 2 Civil Rights & 1.98 & 1.82 & 2.13 & 1.98 \\
\hline 14 Sports and Recreation & 1.88 & 0.82 & 1.78 & 2.00 \\
\hline 1 Community Development \& Housing & 1.81 & 8.17 & 5.17 & 0.81 \\
\hline 30 Macroeconomics & 1.78 & 0.19 & 0.50 & 2.07 \\
\hline 29 Death Notices & 1.73 & 0.25 & 0.61 & 2.00 \\
\hline 7 Environment & 1.42 & 1.82 & 3.39 & 1.16 \\
\hline 31 Churches and Religion & 1.29 & 1.35 & 0.96 & 1.32 \\
\hline 4 Agriculture & 1.07 & 0.35 & 0.93 & 1.16 \\
\hline 13 Social Welfare & 0.68 & 1.35 & 1.72 & 0.50 \\
\hline 21 Public Lands and Water Management & 0.64 & 1.13 & 1.28 & 0.52 \\
\hline 27 Fires & 0.25 & 1.07 & 0.44 & 0.14 \\
\hline \multirow[t]{2}{*}{26 Weather and Natural Disasters } & 0.20 & 0.22 & 0.15 & 0.20 \\
\hline & 100 & 8.27 & 8.91 & 82.83 \\
\hline DEM Democratic topics & 8.32 & 10.31 & 11.76 & 7.75 \\
\hline REP Republican topics & 13.07 & 16.13 & 12.52 & 12.82 \\
\hline
\end{tabular}

Notes: Democratic stories comprise Civil Rights, Health Care, Labor \& Employment and Social Welfare ones. Republican stories comprise Defense and Law \& Crime ones. 
Table 3: Relative frequencies of stories on the New York Times (1946-1997): front page and internal pages

[1]

Major Topic

\begin{tabular}{|c|c|c|c|}
\hline & \\
\hline 19 International Affairs & 13.10 & $\overline{12.74}$ & 18.37 \\
\hline 20 Federal Government Operations & 8.16 & 7.69 & 15.23 \\
\hline 16 Defense & 7.35 & 6.82 & 15.19 \\
\hline 24 State and Local Government Admin. & 5.21 & 5.07 & 7.35 \\
\hline 12 Law, Crime, and Family Issues & 5.72 & 5.72 & 5.78 \\
\hline 15 Banking, Finance and Dom. Commerce & 15.14 & 15.90 & 3.76 \\
\hline 5 Labor \& Employment & 2.68 & 2.62 & 3.59 \\
\hline 1 Macroeconomics & 1.78 & 1.70 & 2.89 \\
\hline 10 Transportation & 3.48 & 3.52 & 2.81 \\
\hline 2 Civil Rights & 1.98 & 1.93 & 2.77 \\
\hline 6 Education & 3.98 & 4.07 & 2.72 \\
\hline 8 Energy & 2.01 & 1.98 & 2.48 \\
\hline 18 Foreign Trade & 2.13 & 2.12 & 2.39 \\
\hline 3 Health & 2.98 & 3.04 & 2.15 \\
\hline 14 Community Development and Housing & 1.81 & 1.79 & 1.98 \\
\hline 17 Space, Science, Technology \& Comm. & 2.19 & 2.22 & 1.86 \\
\hline 99 Other & 4.80 & 5.02 & 1.49 \\
\hline 28 Arts and Entertainment & 6.34 & 6.69 & 1.16 \\
\hline 31 Churches and Religion & 1.29 & 1.30 & 1.16 \\
\hline 13 Social Welfare & 0.68 & 0.65 & 1.11 \\
\hline 4 Agriculture & 1.07 & 1.07 & 1.07 \\
\hline 7 Environment & 1.42 & 1.45 & 0.95 \\
\hline 30 Death Notices & 1.73 & 1.81 & 0.54 \\
\hline 29 Sports and Recreation & 1.88 & 1.98 & 0.41 \\
\hline 21 Public Lands and Water Management & 0.64 & 0.66 & 0.29 \\
\hline 26 Weather and Natural Disasters & 0.20 & 0.19 & 0.29 \\
\hline \multirow[t]{2}{*}{27 Fires } & 0.25 & 0.25 & 0.25 \\
\hline & 100 & 93.70 & 6.30 \\
\hline DEM Democratic topics & 8.32 & 8.23 & 9.62 \\
\hline REP Republican topics & 13.07 & 12.54 & 20.97 \\
\hline
\end{tabular}

Notes: Democratic stories comprise Civil Rights, Health Care, Labor \& Employment and Social Welfare ones. Republican stories comprise Defense and

Law \& Crime ones. $[2]$
Stories not on the $\quad$ Front page stories front page 
Table 4: Relative frequencies of Executive Orders, 1946-1997

[1]

[2]

[3]

\begin{tabular}{lccc} 
Major Topic & Entire sample & $\begin{array}{c}\text { Democratic } \\
\text { Presidents }\end{array}$ & $\begin{array}{c}\text { Republican } \\
\text { Presidents }\end{array}$ \\
\hline \hline 20 Federal Government Operations & 23.43 & 21.50 & 25.76 \\
16 Defense & 20.79 & 21.34 & 20.13 \\
19 International Affairs & 11.35 & 11.31 & 11.39 \\
5 Labor \& Employment & 9.56 & 11.58 & 7.12 \\
21 Public Lands and Water Manag. & 6.16 & 7.08 & 5.05 \\
18 Foreign Trade & 4.40 & 3.81 & 5.11 \\
2 Civil Rights & 4.05 & 4.93 & 2.98 \\
15 Banking, Finance and Dom. Commerce & 2.43 & 1.82 & 3.17 \\
1 Macroeconomics & 2.38 & 1.93 & 2.91 \\
10 Transportation & 2.35 & 2.20 & 2.52 \\
8 Energy & 2.29 & 2.36 & 2.20 \\
17 Space, Science, Tech. \& Comm. & 1.94 & 1.72 & 2.20 \\
12 Law, Crime, and Family & 1.70 & 1.72 & 1.68 \\
7 Environment & 1.58 & 1.61 & 1.55 \\
14 Community Development and Housing & 1.50 & 1.29 & 1.75 \\
3 Health & 1.44 & 1.93 & 0.84 \\
4 Agriculture & 1.03 & 0.86 & 1.23 \\
6 Education & 1.00 & 0.80 & 1.23 \\
13 Social Welfare & 0.65 & 0.21 & 1.17 \\
\hline & & & 12.10 \\
\hline DEM Executive Orders on Democratic topics & 15.69 & 21.81 \\
\hline REP Executive Orders on Republican topics & 22.49 & 18.66 & \\
\hline \hline Notes: Democratic topics comprise Civil Rights, Health Care, Labor \& Employment and Social Welfare. Republican topics comprise Defense and \\
Law \& Crime. & & &
\end{tabular}


Table 5: Poisson estimates for count of stories on Democratic topics, baseline specification

\begin{tabular}{|c|c|c|c|c|c|c|c|}
\hline & $\begin{array}{c}\quad[1] \\
\text { all stories }\end{array}$ & $\begin{array}{c}\text { [2] } \\
\text { domestic stories }\end{array}$ & $\begin{array}{c}{[3]} \\
\text { non-local stories }\end{array}$ & $\begin{array}{c}4] \\
\text { TriState stories }\end{array}$ & $\begin{array}{c}{[5]} \\
\text { NYC stories }\end{array}$ & $\begin{array}{c}{[6]} \\
\text { front page stories }\end{array}$ & $\begin{array}{c}{[7]} \\
\text { stories not on the } \\
\text { front page }\end{array}$ \\
\hline Incumbent President is a Democrat & $\begin{array}{c}1.179 * * * \\
{[4.32]}\end{array}$ & $\begin{array}{c}1.192^{\star \star *} \\
{[4.29]}\end{array}$ & $\begin{array}{c}1.183^{\star \star *} \\
{[3.93]}\end{array}$ & $\begin{array}{l}1.105 \\
{[0.81]}\end{array}$ & $\begin{array}{l}1.204 \\
{[1.38]}\end{array}$ & $\begin{array}{l}1.275^{\star} \\
{[1.69]}\end{array}$ & $\begin{array}{c}1.167^{\star * *} \\
{[3.94]}\end{array}$ \\
\hline Presidential campaign dummy & $\begin{array}{c}1.266^{\star * \star} \\
{[2.90]}\end{array}$ & $\begin{array}{c}1.231^{\star *} \\
{[2.49]}\end{array}$ & $\begin{array}{l}1.167 \\
{[1.64]}\end{array}$ & $\begin{array}{l}1.091 \\
{[0.28]}\end{array}$ & $\begin{array}{c}2.635^{\star \star \star} \\
{[3.72]}\end{array}$ & $\begin{array}{c}1.68 \\
{[1.33]}\end{array}$ & $\begin{array}{c}1.246 * \star * \\
{[2.69]}\end{array}$ \\
\hline $\begin{array}{l}\text { interaction: Presidential campaign \& } \\
\text { incumbent President is a Democrat }\end{array}$ & $\begin{array}{l}0.810^{\star} \\
{[1.71]}\end{array}$ & $\begin{array}{c}0.762^{\star \star} \\
{[2.48]}\end{array}$ & $\begin{array}{l}0.848 \\
{[1.13]}\end{array}$ & $\begin{array}{l}0.891 \\
{[0.24]}\end{array}$ & $\begin{array}{l}0.541 \\
{[1.46]}\end{array}$ & $\begin{array}{l}0.475 \\
{[1.16]}\end{array}$ & $\begin{array}{l}0.834 \\
{[1.52]}\end{array}$ \\
\hline relative frequency of Executive Orders & $\begin{array}{l}0.934 \\
{[0.76]}\end{array}$ & $\begin{array}{l}0.955 \\
{[0.50]}\end{array}$ & $\begin{array}{l}0.911 \\
{[0.92]}\end{array}$ & $\begin{array}{l}0.828 \\
{[0.65]}\end{array}$ & $\begin{array}{l}1.335 \\
{[0.93]}\end{array}$ & $\begin{array}{l}0.772 \\
{[0.69]}\end{array}$ & $\begin{array}{l}0.948 \\
{[0.62]}\end{array}$ \\
\hline total number of stories & $\begin{array}{c}1.014^{\star * \star} \\
{[18.78]}\end{array}$ & $\begin{array}{l}1.004 \\
{[1.15]}\end{array}$ & $\begin{array}{l}0.999 \\
{[0.21]}\end{array}$ & $\begin{array}{c}1 \\
{[0.06]}\end{array}$ & $\begin{array}{l}0.995 \\
{[1.52]}\end{array}$ & $\begin{array}{l}0.997 \\
{[0.90]}\end{array}$ & $\begin{array}{l}0.999 \\
{[0.08]}\end{array}$ \\
\hline $\begin{array}{l}\text { total number of stories in the considered } \\
\text { subset }\end{array}$ & - & $\begin{array}{c}1.014^{\star \star *} \\
{[2.67]}\end{array}$ & $\begin{array}{c}1.019 * * * \\
{[3.86]}\end{array}$ & $\begin{array}{c}1.113^{\star \star *} \\
{[5.36]}\end{array}$ & $\begin{array}{l}1.166^{\star * *} \\
{[7.59]}\end{array}$ & $\begin{array}{l}1.226 * \star \\
{[7.98]}\end{array}$ & $\begin{array}{c}1.016^{\star *} \\
{[2.23]}\end{array}$ \\
\hline $\begin{array}{l}p \text { value for no effects of the campaign when } \\
\text { the incumbent is a Democrat }\end{array}$ & 0.82 & 0.5 & 0.94 & 0.94 & 0.37 & 0.69 & 0.72 \\
\hline Monthly dummies & yes & yes & yes & yes & yes & yes & yes \\
\hline Time trend & yes & yes & yes & yes & yes & yes & yes \\
\hline Time trend squared & yes & yes & yes & yes & yes & yes & yes \\
\hline Observations & 624 & 624 & 624 & 624 & 624 & 624 & 624 \\
\hline Pseudo R2 & 0.16 & 0.15 & 0.13 & 0.12 & 0.12 & 0.11 & 0.16 \\
\hline
\end{tabular}

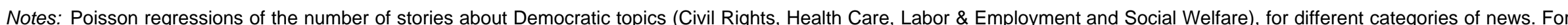

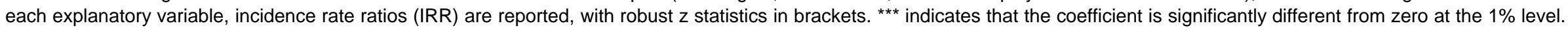
** $\left(^{*}\right)$ indicates 5\% (10\%) significance. 
Table 6: Poisson estimates for count of stories on Defense, baseline specification

\begin{tabular}{|c|c|c|c|c|c|}
\hline & $\begin{array}{c}1] \\
\text { all stories }\end{array}$ & $\begin{array}{c}{[2]} \\
\text { domestic stories }\end{array}$ & $\begin{array}{c}3] \\
\text { non-domestic } \\
\text { stories }\end{array}$ & $\begin{array}{c}{[4]} \\
\text { front page stories }\end{array}$ & $\begin{array}{c}5] \\
\text { stories not on the } \\
\text { front page }\end{array}$ \\
\hline Incumbent President is a Republican & $\begin{array}{c}1.102^{* *} \\
{[2.02]}\end{array}$ & $\begin{array}{l}1.095 \\
{[1.10]}\end{array}$ & $\begin{array}{l}1.118^{\star *} \\
{[2.03]}\end{array}$ & $\begin{array}{l}1.220^{*} \\
{[1.82]}\end{array}$ & $\begin{array}{l}1.089^{*} \\
{[1.65]}\end{array}$ \\
\hline Presidential campaign dummy & $\begin{array}{l}1.064 \\
{[0.35]}\end{array}$ & $\begin{array}{c}1.09 \\
{[0.47]}\end{array}$ & $\begin{array}{l}1.069 \\
{[0.38]}\end{array}$ & $\begin{array}{l}0.879 \\
{[0.35]}\end{array}$ & $\begin{array}{l}1.092 \\
{[0.43]}\end{array}$ \\
\hline $\begin{array}{l}\text { interaction: Presidential campaign \& incumbent } \\
\text { President is a Republican }\end{array}$ & $\begin{array}{l}0.806 \\
{[1.09]}\end{array}$ & $\begin{array}{l}0.694 \\
{[1.35]}\end{array}$ & $\begin{array}{l}0.923 \\
{[0.39]}\end{array}$ & $\begin{array}{l}0.573 \\
{[1.14]}\end{array}$ & $\begin{array}{l}0.846 \\
{[0.73]}\end{array}$ \\
\hline $\begin{array}{l}\text { dummy for campaign years with issue } \\
\text { ownership reversal ('64, '80, '96) }\end{array}$ & $\begin{array}{l}1.029 \\
{[0.11]}\end{array}$ & $\begin{array}{l}1.04 \\
{[0.14]}\end{array}$ & $\begin{array}{l}1.08 \\
{[0.27]}\end{array}$ & $\begin{array}{c}0.86 \\
{[0.26]}\end{array}$ & $\begin{array}{l}1.056 \\
{[0.20]}\end{array}$ \\
\hline monthly Killed In Action (KIA), thousands & $\begin{array}{c}1.348^{\star * \star} \\
{[6.70]}\end{array}$ & $\begin{array}{c}1.147^{* *} \\
{[2.53]}\end{array}$ & $\begin{array}{c}1.472^{\star \star \star} \\
{[6.48]}\end{array}$ & $\begin{array}{c}1.359 * * \star \\
{[3.31]}\end{array}$ & $\begin{array}{c}1.341^{* * *} \\
{[6.14]}\end{array}$ \\
\hline relative frequency of Executive Orders & $\begin{array}{l}1.127 \\
{[1.16]}\end{array}$ & $\begin{array}{c}1.430 * * \\
{[2.35]}\end{array}$ & $\begin{array}{l}1.069 \\
{[0.55]}\end{array}$ & $\begin{array}{l}1.014 \\
{[0.06]}\end{array}$ & $\begin{array}{l}1.129 \\
{[1.11]}\end{array}$ \\
\hline total number of stories & $\begin{array}{l}1.014^{\star * *} \\
{[15.23]}\end{array}$ & $\begin{array}{l}0.998 \\
{[0.34]}\end{array}$ & $\begin{array}{l}0.997 \\
{[1.48]}\end{array}$ & $\begin{array}{l}0.998 \\
{[1.08]}\end{array}$ & $\begin{array}{c}1 \\
{[0.03]}\end{array}$ \\
\hline total number of stories in the considered subset & - & $\begin{array}{c}1.020^{\star \star} \\
{[2.37]}\end{array}$ & $\begin{array}{c}1.063^{\star \star \star} \\
{[8.66]}\end{array}$ & $\begin{array}{c}1.224^{\star \star *} \\
{[11.26]}\end{array}$ & $\begin{array}{l}1.016 \\
{[1.47]}\end{array}$ \\
\hline $\begin{array}{l}\mathrm{p} \text { value for no effects of the campaign when the } \\
\text { incumbent is a Republican }\end{array}$ & 0.22 & 0.2 & 0.92 & 0.07 & 0.54 \\
\hline Monthly dummies & yes & yes & yes & yes & yes \\
\hline Time trend & yes & yes & yes & yes & yes \\
\hline Time trend squared & yes & yes & yes & yes & yes \\
\hline Observations & 624 & 624 & 624 & 624 & 624 \\
\hline Pseudo R2 & 0.24 & 0.16 & 0.22 & 0.18 & 0.22 \\
\hline
\end{tabular}

Notes: Poisson regressions of the number of stories about Defense, for different categories of news. For each explanatory variable, incidence rate ratios $\left(\right.$ IRR) are reported, with robust $z$ statistics in brackets. ${ }^{* \star}$ indicates that the coefficient is significantly different from zero at the $1 \%$ level. ${ }^{* *}\left({ }^{*}\right)$ indicates $5 \%$ (10\%) significance. 
Table 7: Poisson estimates for count of stories on Law \& Crime, baseline specification

\begin{tabular}{|c|c|c|c|c|c|c|c|}
\hline & $\begin{array}{c}1] \\
\text { all stories }\end{array}$ & $\begin{array}{c}{[2]} \\
\text { domestic stories }\end{array}$ & $\begin{array}{c}{[3]} \\
\text { non-local stories }\end{array}$ & $\begin{array}{c}{[4]} \\
\text { TriState stories }\end{array}$ & $\begin{array}{c}{[5]} \\
\text { NYC stories }\end{array}$ & $\begin{array}{c}6] \\
\text { front page stories }\end{array}$ & $\begin{array}{c}{[7]} \\
\text { stories not on the } \\
\text { front page }\end{array}$ \\
\hline \multirow[t]{2}{*}{ Incumbent President is a Republican } & 0.978 & 0.963 & 1.022 & 0.821 & 1.031 & 0.954 & 0.982 \\
\hline & {$[0.48]$} & {$[0.78]$} & {$[0.34]$} & {$[1.52]$} & [0.29] & {$[0.23]$} & {$[0.39]$} \\
\hline \multirow[t]{2}{*}{ Presidential campaign dummy } & 1.005 & 1.033 & 0.899 & 1.433 & 1.107 & 1.801 & 0.956 \\
\hline & {$[0.03]$} & [0.18] & [0.45] & {$[1.00]$} & [0.33] & [1.09] & {$[0.26]$} \\
\hline \multirow{2}{*}{$\begin{array}{l}\text { interaction: Presidential campaign \& } \\
\text { incumbent President is a Republican }\end{array}$} & 1.127 & 0.956 & 1.31 & 1.08 & 0.731 & 1.36 & 1.111 \\
\hline & [0.62] & {$[0.24]$} & [1.06] & {$[0.22]$} & {$[0.79]$} & [0.53] & {$[0.56]$} \\
\hline \multirow{2}{*}{$\begin{array}{l}\text { dummy for campaign years with issue } \\
\text { ownership reversal ('76, '92, '96) }\end{array}$} & 0.966 & 1.071 & 0.907 & 1.358 & 0.763 & 0.346 & 1.034 \\
\hline & {$[0.21]$} & {$[0.40]$} & [0.51] & [0.87] & {$[0.51]$} & [1.05] & {$[0.20]$} \\
\hline \multirow[t]{2}{*}{ relative frequency of Executive Orders } & 1.215 & $1.400^{\star}$ & 1.181 & 1.667 & 1.22 & 1.723 & 1.182 \\
\hline & [1.01] & {$[1.76]$} & [0.67] & [1.11] & {$[0.37]$} & {$[0.73]$} & {$[0.86]$} \\
\hline \multirow[t]{2}{*}{ total number of stories } & $1.015^{\star * *}$ & 1.005 & 0.992 & $1.006^{\star}$ & 1.001 & 1.003 & 1 \\
\hline & {$[15.22]$} & [0.98] & [1.46] & {$[1.78]$} & [0.31] & [0.86] & [0.05] \\
\hline $\begin{array}{l}\text { total number of stories in the considered } \\
\text { subset }\end{array}$ & - & $\begin{array}{l}1.015^{\star \star} \\
{[2.13]}\end{array}$ & $\begin{array}{c}1.026^{\star * *} \\
{[3.70]}\end{array}$ & $\begin{array}{l}1.110^{\star \star *} \\
{[6.70]}\end{array}$ & $\begin{array}{c}1.146 * \star \star \\
{[8.53]}\end{array}$ & $\begin{array}{c}1.213^{\star \star \star} \\
{[7.17]}\end{array}$ & $\begin{array}{l}1.016^{\star} \\
{[1.75]}\end{array}$ \\
\hline $\begin{array}{l}\mathrm{p} \text { value for no effects of the campaign } \\
\text { when the incumbent is a Republican }\end{array}$ & 0.36 & 0.92 & 0.36 & 0.11 & 0.49 & 0.03 & 0.65 \\
\hline Monthly dummies & yes & yes & yes & yes & yes & yes & yes \\
\hline Time trend & yes & yes & yes & yes & yes & yes & yes \\
\hline Time trend squared & yes & yes & yes & yes & yes & yes & yes \\
\hline Observations & 624 & 624 & 624 & 624 & 624 & 624 & 624 \\
\hline Pseudo R2 & 0.16 & 0.16 & 0.09 & 0.16 & 0.15 & 0.11 & 0.15 \\
\hline
\end{tabular}

Notes: Poisson regressions of the number of stories about Law \& Crime, for different categories of news. For each explanatory variable, incidence rate ratios (IRR) are reported with robust $z$ statistics in brackets. ${ }^{\star \star \star}$ indicates that the coefficient is significantly different from zero at the $1 \%$ level. ${ }^{\star \star}\left({ }^{\star}\right)$ indicates $5 \%(10 \%)$ significance. 
Table 8: Poisson estimates for count of stories on Democratic topics, controlling for NYS Governor, NYC Mayor and NYT publisher

\begin{tabular}{|c|c|c|c|c|c|c|c|}
\hline & $\begin{array}{c}1] \\
\text { all stories }\end{array}$ & $\begin{array}{c}{[2]} \\
\text { domestic stories }\end{array}$ & $\begin{array}{c}{[3]} \\
\text { non-local stories }\end{array}$ & $\begin{array}{l}4] \\
\text { tristate stories }\end{array}$ & $\begin{array}{c}{[5]} \\
\text { NYC stories }\end{array}$ & $\begin{array}{c}{[6]} \\
\text { front page stories }\end{array}$ & $\begin{array}{c}{[7]} \\
\text { stories not on the } \\
\text { front page }\end{array}$ \\
\hline Incumbent President is a Democrat & $\begin{array}{c}1.110 * \star \\
{[2.18]}\end{array}$ & $\begin{array}{l}1.101^{*} \\
{[1.91]}\end{array}$ & $\begin{array}{c}1.05 \\
{[0.85]}\end{array}$ & $\begin{array}{c}1.389 * * \\
{[2.18]}\end{array}$ & $\begin{array}{l}1.265 \\
{[1.42]}\end{array}$ & $\begin{array}{l}1.176 \\
{[0.84]}\end{array}$ & $\begin{array}{l}1.100 * \\
{[1.90]}\end{array}$ \\
\hline Presidential campaign dummy & $\begin{array}{c}1.267^{* * *} \\
{[2.96]}\end{array}$ & $\begin{array}{c}1.230 * \star \\
{[2.54]}\end{array}$ & $\begin{array}{l}1.172^{*} \\
{[1.69]}\end{array}$ & $\begin{array}{l}1.033 \\
{[0.10]}\end{array}$ & $\begin{array}{c}2.613^{* * *} \\
{[3.72]}\end{array}$ & $\begin{array}{l}1.683 \\
{[1.34]}\end{array}$ & $\begin{array}{c}1.246^{\star * *} \\
{[2.80]}\end{array}$ \\
\hline $\begin{array}{l}\text { interaction: Presidential campaign \& incumbent } \\
\text { President is a Democrat }\end{array}$ & $\begin{array}{l}0.802^{\star} \\
{[1.69]}\end{array}$ & $\begin{array}{c}0.755^{\star \star} \\
{[2.49]}\end{array}$ & $\begin{array}{c}0.84 \\
{[1.11]}\end{array}$ & $\begin{array}{l}0.891 \\
{[0.25]}\end{array}$ & $\begin{array}{l}0.513 \\
{[1.60]}\end{array}$ & $\begin{array}{l}0.465 \\
{[1.18]}\end{array}$ & $\begin{array}{l}0.825 \\
{[1.53]}\end{array}$ \\
\hline Incumbent NYS Governor is a Democrat & $\begin{array}{l}1.103^{*} \\
{[1.68]}\end{array}$ & $\begin{array}{c}1.08 \\
{[1.28]}\end{array}$ & $\begin{array}{l}0.974 \\
{[0.43]}\end{array}$ & $\begin{array}{c}1.774^{* \star \star} \\
{[3.46]}\end{array}$ & $\begin{array}{l}1.326 \\
{[1.34]}\end{array}$ & $\begin{array}{c}1.17 \\
{[0.69]}\end{array}$ & $\begin{array}{l}1.097 \\
{[1.56]}\end{array}$ \\
\hline Incumbent NYC Mayor is a Democrat & $\begin{array}{c}0.863^{\star \star} \\
{[2.45]}\end{array}$ & $\begin{array}{c}0.877^{\star *} \\
{[2.11]}\end{array}$ & $\begin{array}{l}0.933 \\
{[1.05]}\end{array}$ & $\begin{array}{c}0.610^{* * \star} \\
{[2.75]}\end{array}$ & $\begin{array}{l}0.646^{*} \\
{[1.90]}\end{array}$ & $\begin{array}{l}1.058 \\
{[0.25]}\end{array}$ & $\begin{array}{c}0.847^{* * *} \\
{[2.70]}\end{array}$ \\
\hline Orvil Dryfoos publisher dummy & $\begin{array}{l}0.928 \\
{[0.58]}\end{array}$ & $\begin{array}{l}0.917 \\
{[0.66]}\end{array}$ & $\begin{array}{l}1.038 \\
{[0.25]}\end{array}$ & $\begin{array}{l}0.544 \\
{[1.18]}\end{array}$ & $\begin{array}{l}0.515 \\
{[1.19]}\end{array}$ & $\begin{array}{l}0.915 \\
{[0.19]}\end{array}$ & $\begin{array}{l}0.925 \\
{[0.54]}\end{array}$ \\
\hline Arthur Ochs Sulzberger publisher dummy & $\begin{array}{c}1.305^{\star *} \\
{[2.25]}\end{array}$ & $\begin{array}{c}1.378^{\star \star \star} \\
{[2.68]}\end{array}$ & $\begin{array}{c}1.428^{\star \star} \\
{[2.54]}\end{array}$ & $\begin{array}{l}0.591 \\
{[1.27]}\end{array}$ & $\begin{array}{l}1.108 \\
{[0.23]}\end{array}$ & $\begin{array}{l}1.927 \\
{[1.30]}\end{array}$ & $\begin{array}{l}1.256^{\star} \\
{[1.83]}\end{array}$ \\
\hline Arthur Sulzberger Jr. publisher dummy & $\begin{array}{c}1.483^{* *} \\
{[2.10]}\end{array}$ & $\begin{array}{c}1.655^{\star \star \star} \\
{[2.69]}\end{array}$ & $\begin{array}{c}1.808^{\star \star *} \\
{[2.70]}\end{array}$ & $\begin{array}{l}0.427 \\
{[1.30]}\end{array}$ & $\begin{array}{c}0.78 \\
{[0.35]}\end{array}$ & $\begin{array}{l}2.242 \\
{[1.04]}\end{array}$ & $\begin{array}{l}1.437^{*} \\
{[1.90]}\end{array}$ \\
\hline $\begin{array}{l}\text { value for no effects of the presidential campaign } \\
\text { when the incumbent President is a Democrat }\end{array}$ & 0.9 & 0.45 & 0.91 & 0.83 & 0.46 & 0.67 & 0.81 \\
\hline Monthly dummies & yes & yes & yes & yes & yes & yes & yes \\
\hline Time trend and time trend squared & yes & yes & yes & yes & yes & yes & yes \\
\hline Executive Orders and total number of stories & yes & yes & yes & yes & yes & yes & yes \\
\hline Observations & 624 & 624 & 624 & 624 & 624 & 624 & 624 \\
\hline Pseudo R2 & 0.17 & 0.15 & 0.14 & 0.13 & 0.13 & 0.11 & 0.17 \\
\hline
\end{tabular}

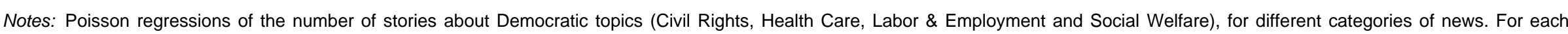

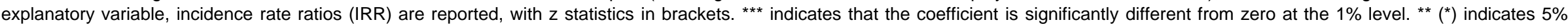
$(10 \%)$ significance. 
Table 9: count of stories on Defense, controlling for NYS Governor, NYC Mayor and NYT publisher

\begin{tabular}{|c|c|c|c|c|c|}
\hline & $\begin{array}{l}1] \\
\text { all stories }\end{array}$ & $\begin{array}{c}{[2]} \\
\text { domestic stories }\end{array}$ & $\begin{array}{c}\text { [3] } \\
\text { non-domestic } \\
\text { stories }\end{array}$ & $\begin{array}{c}{[4]} \\
\text { front page stories }\end{array}$ & $\begin{array}{l}{[5]} \\
\text { stories not on the } \\
\text { front page }\end{array}$ \\
\hline Incumbent President is a Republican & $\begin{array}{l}1.274^{\star * *} \\
{[3.55]}\end{array}$ & $\begin{array}{l}1.212^{*} \\
{[1.75]}\end{array}$ & $\begin{array}{l}1.319 * * * \\
{[3.62]}\end{array}$ & $\begin{array}{l}1.214 \\
{[1.21]}\end{array}$ & $\begin{array}{l}1.268^{\star * \star} \\
{[3.21]}\end{array}$ \\
\hline Presidential campaign dummy & $\begin{array}{l}1.071 \\
{[0.39]}\end{array}$ & $\begin{array}{l}1.115 \\
{[0.58]}\end{array}$ & $\begin{array}{l}1.083 \\
{[0.43]}\end{array}$ & $\begin{array}{l}0.843 \\
{[0.45]}\end{array}$ & $\begin{array}{l}1.103 \\
{[0.48]}\end{array}$ \\
\hline $\begin{array}{l}\text { interaction: Presidential campaign \& incumbent President } \\
\text { is a Republican }\end{array}$ & $\begin{array}{l}0.838 \\
{[0.86]}\end{array}$ & $\begin{array}{c}0.69 \\
{[1.37]}\end{array}$ & $\begin{array}{c}0.98 \\
{[0.09]}\end{array}$ & $\begin{array}{l}0.617 \\
{[0.99]}\end{array}$ & $\begin{array}{l}0.877 \\
{[0.56]}\end{array}$ \\
\hline $\begin{array}{l}\text { dummy for campaign years with issue ownership reversal } \\
\left(' 64,{ }^{\prime} 80, ' 96\right)\end{array}$ & $\begin{array}{l}1.073 \\
{[0.28]}\end{array}$ & $\begin{array}{l}1.012 \\
{[0.04]}\end{array}$ & $\begin{array}{l}1.119 \\
{[0.40]}\end{array}$ & $\begin{array}{c}0.95 \\
{[0.09]}\end{array}$ & $\begin{array}{l}1.096 \\
{[0.34]}\end{array}$ \\
\hline monthly Killed In Action (KIA), thousands & $\begin{array}{c}1.311^{\star * \star} \\
{[6.51]}\end{array}$ & $\begin{array}{c}1.153^{\star * \star} \\
{[2.64]}\end{array}$ & $\begin{array}{l}1.418^{\star \star \star} \\
{[6.14]}\end{array}$ & $\begin{array}{l}1.277^{* \star} \\
{[2.14]}\end{array}$ & $\begin{array}{l}1.310^{\star \star \star} \\
{[6.04]}\end{array}$ \\
\hline Incumbent NYS Governor is a Republican & $\begin{array}{l}0.929 \\
{[0.99]}\end{array}$ & $\begin{array}{l}1.106 \\
{[0.87]}\end{array}$ & $\begin{array}{l}0.885 \\
{[1.52]}\end{array}$ & $\begin{array}{l}1.002 \\
{[0.01]}\end{array}$ & $\begin{array}{l}0.926 \\
{[0.97]}\end{array}$ \\
\hline Incumbent NYC Mayor is a Republican & $\begin{array}{l}1.138 \\
{[1.59]}\end{array}$ & $\begin{array}{l}0.903 \\
{[0.79]}\end{array}$ & $\begin{array}{l}1.151^{*} \\
{[1.70]}\end{array}$ & $\begin{array}{l}1.214 \\
{[1.01]}\end{array}$ & $\begin{array}{l}1.115 \\
{[1.29]}\end{array}$ \\
\hline Orvil Dryfoos publisher dummy & $\begin{array}{c}1.642^{\star \star \star} \\
{[2.96]}\end{array}$ & $\begin{array}{c}1.23 \\
{[0.78]}\end{array}$ & $\begin{array}{c}1.765^{\star \star \star} \\
{[2.88]}\end{array}$ & $\begin{array}{l}1.057 \\
{[0.15]}\end{array}$ & $\begin{array}{c}1.678^{\star \star \star} \\
{[2.72]}\end{array}$ \\
\hline Arthur Ochs Sulzberger publisher dummy & $\begin{array}{c}1.880 * \star \star * \\
{[3.60]}\end{array}$ & $\begin{array}{l}1.289 \\
{[0.97]}\end{array}$ & $\begin{array}{c}2.336^{\star \star \star} \\
{[4.42]}\end{array}$ & $\begin{array}{l}1.126 \\
{[0.29]}\end{array}$ & $\begin{array}{c}1.972^{\star \star \star} \\
{[3.52]}\end{array}$ \\
\hline Arthur Sulzberger Jr. publisher dummy & $\begin{array}{l}1.378 \\
{[1.11]}\end{array}$ & $\begin{array}{l}1.439 \\
{[0.84]}\end{array}$ & $\begin{array}{l}1.483 \\
{[1.18]}\end{array}$ & $\begin{array}{l}0.451 \\
{[0.96]}\end{array}$ & $\begin{array}{l}1.491 \\
{[1.32]}\end{array}$ \\
\hline $\begin{array}{l}\text { p value for no effects of the presidential campaign when } \\
\text { the incumbent President is a Republican }\end{array}$ & 0.4 & 0.22 & 0.67 & 0.07 & 0.81 \\
\hline Monthly dummies & yes & yes & yes & yes & yes \\
\hline Time trend and time trend squared & yes & yes & yes & yes & yes \\
\hline Executive Orders and total number of stories & yes & yes & yes & yes & yes \\
\hline Observations & 624 & 624 & 624 & 624 & 624 \\
\hline Pseudo R2 & 0.25 & 0.16 & 0.23 & 0.19 & 0.23 \\
\hline
\end{tabular}

Notes: Poisson regressions of the number of stories about Defense, for different categories of news. For each explanatory variable, incidence rate ratios (IRR) are reported, with robust $z$ statistics in brackets. ${ }^{\star \star \star}$ indicates that the coefficient is significantly different from zero at the $1 \%$ level. ${ }^{\star \star}\left({ }^{\star}\right)$ indicates $5 \%(10 \%)$ significance. 
Table 10: count of stories on Law \& Crime, controlling for presidential activity, NYS Governor, NYC Mayor and NYT publisher

\begin{tabular}{|c|c|c|c|c|c|c|c|}
\hline & $\begin{array}{l}{[1]} \\
\text { all stories }\end{array}$ & $\begin{array}{c}{[2]} \\
\text { domestic stories }\end{array}$ & $\begin{array}{c}\text { [3] } \\
\text { non-local stories }\end{array}$ & $\begin{array}{c}\text { [4] } \\
\text { tristate stories }\end{array}$ & $\begin{array}{c}{[5]} \\
\text { NYC stories }\end{array}$ & $\begin{array}{c}{[6]} \\
\text { front page stories }\end{array}$ & $\begin{array}{l}{[7]} \\
\text { stories not on the } \\
\text { front page }\end{array}$ \\
\hline \multirow[t]{2}{*}{ Incumbent President is a Republican } & 1.025 & 1.029 & 1.094 & 0.804 & 1.016 & 1.011 & 1.029 \\
\hline & {$[0.42]$} & {$[0.46]$} & [1.11] & [1.33] & {$[0.10]$} & {$[0.04]$} & {$[0.47]$} \\
\hline \multirow[t]{2}{*}{ Presidential campaign dummy } & 0.988 & 1.02 & 0.913 & 1.316 & 0.986 & 1.658 & 0.942 \\
\hline & {$[0.07]$} & {$[0.11]$} & [0.38] & {$[0.76]$} & {$[0.05]$} & [0.94] & [0.34] \\
\hline \multirow{2}{*}{$\begin{array}{l}\text { interaction: Presidential campaign \& incumbent President } \\
\text { is a Republican }\end{array}$} & 1.165 & 0.98 & 1.331 & 1.082 & 0.8 & 1.445 & 1.147 \\
\hline & {$[0.78]$} & {$[0.10]$} & [1.09] & {$[0.22]$} & {$[0.58]$} & [0.64] & {$[0.71]$} \\
\hline \multirow{2}{*}{$\begin{array}{l}\text { dummy for campaign years with issue ownership reversal } \\
(' 76, ' 92, ' 96)\end{array}$} & 0.954 & 1.045 & 0.822 & 1.663 & 0.865 & 0.317 & 1.02 \\
\hline & {$[0.27]$} & {$[0.25]$} & [0.99] & [1.39] & {$[0.27]$} & [1.08] & {$[0.11]$} \\
\hline \multirow[t]{2}{*}{ Incumbent NYS Governor is a Republican } & 0.931 & 0.902 & $0.819 * *$ & 0.829 & 1.242 & 0.972 & 0.931 \\
\hline & {$[1.04]$} & {$[1.44]$} & [2.07] & [1.03] & [1.49] & {$[0.10]$} & [1.02] \\
\hline \multirow[t]{2}{*}{ Incumbent NYC Mayor is a Republican } & $1.122^{*}$ & $1.188^{\star *}$ & 1.007 & $1.810^{\star \star \star}$ & 1.206 & 1.176 & 1.113 \\
\hline & {$[1.67]$} & [2.29] & {$[0.09]$} & [3.15] & [1.23] & {$[0.54]$} & [1.54] \\
\hline \multirow[t]{2}{*}{ Orvil Dryfoos publisher dummy } & 0.779 & 0.808 & 0.938 & 0.823 & 0.477 & 0.249 & 0.834 \\
\hline & [1.08] & {$[0.92]$} & {$[0.25]$} & {$[0.36]$} & [1.59] & [1.30] & {$[0.80]$} \\
\hline \multirow[t]{2}{*}{ Arthur Ochs Sulzberger publisher dummy } & $1.452^{\star \star}$ & $1.529 * \star$ & $1.890 * \star \star$ & 0.99 & 0.963 & 1.167 & $1.471^{\star *}$ \\
\hline & [2.08] & {$[2.29]$} & [2.65] & {$[0.02]$} & {$[0.11]$} & {$[0.26]$} & [2.03] \\
\hline \multirow[t]{2}{*}{ Arthur Sulzberger Jr. publisher dummy } & 1.437 & $1.556^{\star}$ & $2.180 * \star$ & 0.523 & 0.629 & 1.655 & 1.441 \\
\hline & {$[1.50]$} & {$[1.74]$} & {$[2.57]$} & [0.98] & [0.81] & {$[0.52]$} & [1.43] \\
\hline $\begin{array}{l}\mathrm{p} \text { value for no effects of the presidential campaign when } \\
\text { the incumbent President is a Republican }\end{array}$ & 0.3 & 1 & 0.28 & 0.2 & 0.42 & 0.03 & 0.56 \\
\hline Monthly dummies & yes & yes & yes & yes & yes & yes & yes \\
\hline Time trend and time trend squared & yes & yes & yes & yes & yes & yes & yes \\
\hline Executive Orders and total number of stories & yes & yes & yes & yes & yes & yes & yes \\
\hline Observations & 624 & 624 & 624 & 624 & 624 & 624 & 624 \\
\hline Pseudo R2 & 0.17 & 0.17 & 0.1 & 0.17 & 0.16 & 0.11 & 0.16 \\
\hline
\end{tabular}

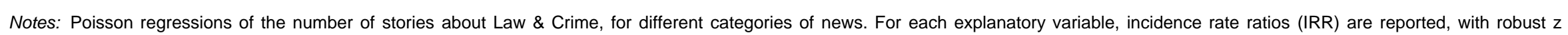
statistics in brackets. ${ }^{* \star}$ indicates that the coefficient is significantly different from zero at the $1 \%$ level. ${ }^{* *}\left(^{\star}\right)$ indicates $5 \%(10 \%)$ significance. 
Table 11: count of stories on Democratic topics, from 1961 to 1997, controlling for NYS Governor, NYC Mayor and NYT Publisher

\begin{tabular}{|c|c|c|c|c|c|c|c|}
\hline & $\begin{array}{c}\text { [1] } \\
\text { all stories }\end{array}$ & $\begin{array}{c}{[2]} \\
\text { domestic stories }\end{array}$ & $\begin{array}{c}{[3]} \\
\text { non-local stories }\end{array}$ & $\begin{array}{c}\text { [4] } \\
\text { tristate stories }\end{array}$ & $\begin{array}{c}{[5]} \\
\text { NYC stories }\end{array}$ & $\begin{array}{c}6] \\
\text { front page stories }\end{array}$ & $\begin{array}{c}{[7]} \\
\text { stories not on the } \\
\text { front page }\end{array}$ \\
\hline Incumbent President is a Democrat & $\begin{array}{c}1.128 \star \star \\
{[2.05]}\end{array}$ & $\begin{array}{l}1.115^{\star} \\
{[1.74]}\end{array}$ & $\begin{array}{l}1.058 \\
{[0.79]}\end{array}$ & $\begin{array}{l}1.399 * \\
{[1.85]}\end{array}$ & $\begin{array}{c}1.37 \\
{[1.57]}\end{array}$ & $\begin{array}{l}1.086 \\
{[0.37]}\end{array}$ & $\begin{array}{c}1.128 * \star \\
{[1.98]}\end{array}$ \\
\hline Presidential campaign dummy & $\begin{array}{c}1.326^{\star \star \star} \\
{[3.18]}\end{array}$ & $\begin{array}{c}1.269 \star \star \\
{[2.53]}\end{array}$ & $\begin{array}{l}1.201^{\star} \\
{[1.73]}\end{array}$ & $\begin{array}{l}0.934 \\
{[0.19]}\end{array}$ & $\begin{array}{c}3.360^{* * \star} \\
{[4.24]}\end{array}$ & $\begin{array}{l}2.195^{\star} \\
{[1.93]}\end{array}$ & $\begin{array}{c}1.290 \star \star \star \\
{[2.86]}\end{array}$ \\
\hline $\begin{array}{l}\text { interaction: Presidential campaign \& incumbent } \\
\text { President is a Democrat }\end{array}$ & $\begin{array}{l}0.765 \\
{[1.56]}\end{array}$ & $\begin{array}{c}0.735^{\star \star} \\
{[2.09]}\end{array}$ & $\begin{array}{l}0.864 \\
{[0.71]}\end{array}$ & $\begin{array}{l}0.541 \\
{[1.16]}\end{array}$ & $\begin{array}{l}0.412^{\star \star} \\
{[2.00]}\end{array}$ & $\begin{array}{l}0.446 \\
{[1.11]}\end{array}$ & $\begin{array}{l}0.787 \\
{[1.49]}\end{array}$ \\
\hline relative frequency of Executive Orders & $\begin{array}{c}1.03 \\
{[0.30]}\end{array}$ & $\begin{array}{l}1.038 \\
{[0.37]}\end{array}$ & $\begin{array}{l}0.976 \\
{[0.21]}\end{array}$ & $\begin{array}{l}1.038 \\
{[0.12]}\end{array}$ & $\begin{array}{l}1.488 \\
{[1.30]}\end{array}$ & $\begin{array}{l}0.616 \\
{[1.07]}\end{array}$ & $\begin{array}{l}1.069 \\
{[0.69]}\end{array}$ \\
\hline Incumbent NYS Governor is a Democrat & $\begin{array}{c}1.237^{\star \star} \\
{[2.04]}\end{array}$ & $\begin{array}{l}1.225^{\star} \\
{[1.89]}\end{array}$ & $\begin{array}{l}1.085 \\
{[0.70]}\end{array}$ & $\begin{array}{c}1.995^{\star \star \star} \\
{[2.67]}\end{array}$ & $\begin{array}{l}1.296 \\
{[0.75]}\end{array}$ & $\begin{array}{c}2.885^{\star \star} \\
{[2.33]}\end{array}$ & $\begin{array}{l}1.177 \\
{[1.57]}\end{array}$ \\
\hline Incumbent NYC Mayor is a Democrat & $\begin{array}{c}0.816^{\star * *} \\
{[2.87]}\end{array}$ & $\begin{array}{c}0.833^{\star \star} \\
{[2.54]}\end{array}$ & $\begin{array}{l}0.893 \\
{[1.45]}\end{array}$ & $\begin{array}{c}0.526 * * \star \\
{[2.92]}\end{array}$ & $\begin{array}{l}0.653^{*} \\
{[1.73]}\end{array}$ & $\begin{array}{l}0.749 \\
{[1.04]}\end{array}$ & $\begin{array}{c}0.815^{\star * *} \\
{[2.81]}\end{array}$ \\
\hline Arthur Ochs Sulzberger publisher dummy & $\begin{array}{c}1.457^{\star \star \star} \\
{[2.85]}\end{array}$ & $\begin{array}{c}1.593^{\star \star \star} \\
{[3.69]}\end{array}$ & $\begin{array}{c}1.455^{\star \star} \\
{[2.46]}\end{array}$ & $\begin{array}{l}0.747 \\
{[0.59]}\end{array}$ & $\begin{array}{l}2.919 * \\
{[1.83]}\end{array}$ & $\begin{array}{l}2.149 * \\
{[1.68]}\end{array}$ & $\begin{array}{c}1.409 * \star \\
{[2.41]}\end{array}$ \\
\hline Arthur Sulzberger Jr. publisher dummy & $\begin{array}{c}1.574^{\star \star} \\
{[2.53]}\end{array}$ & $\begin{array}{c}1.784^{\star * *} \\
{[3.32]}\end{array}$ & $\begin{array}{c}1.723^{\star \star \star} \\
{[2.63]}\end{array}$ & $\begin{array}{l}0.697 \\
{[0.54]}\end{array}$ & $\begin{array}{l}1.726 \\
{[0.75]}\end{array}$ & $\begin{array}{l}2.181 \\
{[1.19]}\end{array}$ & $\begin{array}{c}1.525^{\star \star} \\
{[2.30]}\end{array}$ \\
\hline $\begin{array}{l}\mathrm{p} \text { value for no effects of the presidential campaign } \\
\text { when the incumbent President is a Democrat }\end{array}$ & 0.93 & 0.59 & 0.85 & 0.1 & 0.45 & 0.98 & 0.91 \\
\hline Monthly dummies & yes & yes & yes & yes & yes & yes & yes \\
\hline Time trend and time trend squared & yes & yes & yes & yes & yes & yes & yes \\
\hline Executive Orders and total number of stories & yes & yes & yes & yes & yes & yes & yes \\
\hline Observations & 444 & 444 & 444 & 444 & 444 & 444 & 444 \\
\hline Pseudo R2 & 0.17 & 0.16 & 0.13 & 0.16 & 0.13 & 0.16 & 0.16 \\
\hline
\end{tabular}

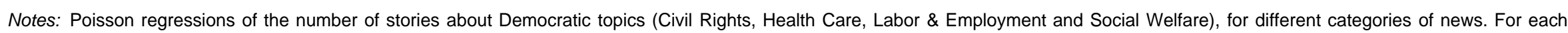

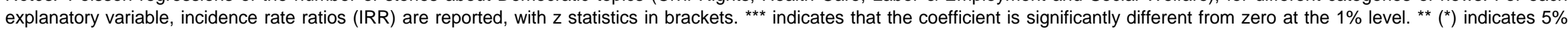
(10\%) significance. 
Table 12: count of stories on Defense, from 1961 to 1997, controlling for NYS Governor, NYC Mayor and NYT publisher

\begin{tabular}{|c|c|c|c|c|c|}
\hline & $\begin{array}{c}1] \\
\text { all stories }\end{array}$ & $\begin{array}{c}{[2]} \\
\text { domestic stories }\end{array}$ & $\begin{array}{c}3] \\
\text { non-domestic } \\
\text { stories }\end{array}$ & $\begin{array}{c}4] \\
\text { front page stories }\end{array}$ & $\begin{array}{c}{[5]} \\
\text { stories not on the } \\
\text { front page }\end{array}$ \\
\hline Incumbent President is a Republican & $\begin{array}{c}1.519 * * * \\
{[5.08]}\end{array}$ & $\begin{array}{c}1.523^{\star * *} \\
{[2.86]}\end{array}$ & $\begin{array}{c}1.506^{\star * *} \\
{[4.40]}\end{array}$ & $\begin{array}{l}1.473^{*} \\
{[1.70]}\end{array}$ & $\begin{array}{c}1.492^{\star \star *} \\
{[4.62]}\end{array}$ \\
\hline Presidential campaign dummy & $\begin{array}{c}1.610^{* * *} \\
{[3.84]}\end{array}$ & $\begin{array}{c}2.147^{* * *} \\
{[3.06]}\end{array}$ & $\begin{array}{c}1.432^{\star *} \\
{[2.47]}\end{array}$ & $\begin{array}{l}0.521 \\
{[1.15]}\end{array}$ & $\begin{array}{c}1.837^{* * *} \\
{[4.74]}\end{array}$ \\
\hline $\begin{array}{l}\text { interaction: Presidential campaign \& incumbent } \\
\text { President is a Republican }\end{array}$ & $\begin{array}{c}0.483^{* * *} \\
{[5.25]}\end{array}$ & $\begin{array}{l}0.390^{* \star *} \\
{[3.05]}\end{array}$ & $\begin{array}{c}0.602^{\star \star *} \\
{[2.64]}\end{array}$ & $\begin{array}{l}1.007 \\
{[0.01]}\end{array}$ & $\begin{array}{c}0.450 * \star * \\
{[5.47]}\end{array}$ \\
\hline $\begin{array}{l}\text { dummy for campaign years with issue ownership } \\
\text { reversal ('64, '80, '96) }\end{array}$ & $\begin{array}{l}0.725 \\
{[1.60]}\end{array}$ & $\begin{array}{l}0.539^{*} \\
{[1.81]}\end{array}$ & $\begin{array}{l}0.883 \\
{[0.49]}\end{array}$ & $\begin{array}{l}1.204 \\
{[0.26]}\end{array}$ & $\begin{array}{l}0.700^{*} \\
{[1.78]}\end{array}$ \\
\hline monthly Killed In Action (KIA), thousands & $\begin{array}{c}1.338^{\star * *} \\
{[2.76]}\end{array}$ & $\begin{array}{l}0.825 \\
{[1.05]}\end{array}$ & $\begin{array}{c}1.510^{* * *} \\
{[4.05]}\end{array}$ & $\begin{array}{l}0.925 \\
{[0.34]}\end{array}$ & $\begin{array}{c}1.395^{\star \star *} \\
{[2.95]}\end{array}$ \\
\hline Incumbent NYS Governor is a Republican & $\begin{array}{l}0.724^{* *} \\
{[2.37]}\end{array}$ & $\begin{array}{l}0.875 \\
{[0.60]}\end{array}$ & $\begin{array}{l}0.692^{\star * *} \\
{[2.68]}\end{array}$ & $\begin{array}{c}0.79 \\
{[0.63]}\end{array}$ & $\begin{array}{l}0.724^{* *} \\
{[2.28]}\end{array}$ \\
\hline Incumbent NYC Mayor is a Republican & $\begin{array}{l}1.209^{*} \\
{[1.83]}\end{array}$ & $\begin{array}{l}1.059 \\
{[0.34]}\end{array}$ & $\begin{array}{c}1.224^{* *} \\
{[2.06]}\end{array}$ & $\begin{array}{l}1.478 \\
{[1.56]}\end{array}$ & $\begin{array}{l}1.175 \\
{[1.51]}\end{array}$ \\
\hline Arthur Ochs Sulzberger publisher dummy & $\begin{array}{l}1.207 \\
{[1.12]}\end{array}$ & $\begin{array}{l}1.286 \\
{[0.96]}\end{array}$ & $\begin{array}{l}1.206 \\
{[0.96]}\end{array}$ & $\begin{array}{l}1.619 \\
{[1.56]}\end{array}$ & $\begin{array}{l}1.129 \\
{[0.66]}\end{array}$ \\
\hline Arthur Sulzberger Jr. publisher dummy & $\begin{array}{l}1.125 \\
{[0.48]}\end{array}$ & $\begin{array}{l}1.617 \\
{[1.25]}\end{array}$ & $\begin{array}{l}1.052 \\
{[0.18]}\end{array}$ & $\begin{array}{l}0.462 \\
{[1.03]}\end{array}$ & $\begin{array}{l}1.175 \\
{[0.64]}\end{array}$ \\
\hline $\begin{array}{l}\mathrm{p} \text { value for no effects of the presidential campaign } \\
\text { when the incumbent President is a Republican }\end{array}$ & 0.06 & 0.43 & 0.37 & 0.06 & 0.16 \\
\hline $\begin{array}{l}\text { p value for no effects of the presidential campaign } \\
\text { during ownership reversal campaigns }\end{array}$ & 0.43 & 0.6 & 0.3 & 0.3 & 0.2 \\
\hline Monthly dummies & yes & yes & yes & yes & yes \\
\hline Time trend and time trend squared & yes & yes & yes & yes & yes \\
\hline Executive Orders and total number of stories & yes & yes & yes & yes & yes \\
\hline Observations & 444 & 444 & 444 & 444 & 444 \\
\hline Pseudo R2 & 0.24 & 0.11 & 0.25 & 0.2 & 0.22 \\
\hline
\end{tabular}

Notes: Poisson regressions of the number of stories about Defense, for different categories of news. For each explanatory variable, incidence rate ratios (IRR) are reported, with robust $z$ statistics in brackets. ${ }^{* *}$ indicates that the coefficient is significantly different from zero at the $1 \%$ level. ${ }^{\star *}\left({ }^{\star}\right)$ indicates $5 \%(10 \%)$ significance. 
Table 13: count of stories on Law \& Crime, from 1961 to 1997, controlling for NYS Governor, NYC Mayor and NYT publisher

\begin{tabular}{|c|c|c|c|c|c|c|c|}
\hline & $\begin{array}{l}\text { [1] } \\
\text { all stories }\end{array}$ & $\begin{array}{c}{[2]} \\
\text { domestic stories }\end{array}$ & $\begin{array}{c}{[3]} \\
\text { non-local stories }\end{array}$ & $\begin{array}{c}\quad[4] \\
\text { tristate stories }\end{array}$ & $\begin{array}{c}{[5]} \\
\text { NYC stories }\end{array}$ & $\begin{array}{c}6] \\
\text { front page stories }\end{array}$ & $\begin{array}{c}{[7]} \\
\text { stories not on the } \\
\text { front page }\end{array}$ \\
\hline \multirow[t]{2}{*}{ Incumbent President is a Republican } & 1.073 & 1.071 & $1.210^{\star \star}$ & 0.844 & 0.947 & 1.217 & 1.059 \\
\hline & [1.16] & [1.04] & [2.17] & [0.92] & {$[0.34]$} & {$[0.71]$} & {$[0.90]$} \\
\hline \multirow[t]{2}{*}{ Presidential campaign dummy } & 1.034 & 1.082 & 1.079 & 1.461 & 0.71 & 2.065 & 0.981 \\
\hline & {$[0.17]$} & [0.39] & [0.29] & {$[0.86]$} & [0.91] & {$[1.17]$} & {$[0.10]$} \\
\hline \multirow{2}{*}{$\begin{array}{l}\text { interaction: Presidential campaign \& incumbent President } \\
\text { is a Republican }\end{array}$} & 1.097 & 0.987 & 1.025 & 1.206 & 1.016 & 1.117 & 1.091 \\
\hline & {$[0.45]$} & {$[0.06]$} & [0.09] & {$[0.46]$} & [0.03] & [0.18] & {$[0.42]$} \\
\hline \multirow{2}{*}{$\begin{array}{l}\text { dummy for campaign years with issue ownership reversal } \\
(' 76, ' 92, ' 96)\end{array}$} & 0.954 & 1.003 & 0.837 & 1.438 & 1.074 & 0.301 & 1.031 \\
\hline & {$[0.26]$} & {$[0.01]$} & [0.82] & [0.98] & [0.13] & [1.12] & {$[0.16]$} \\
\hline \multirow[t]{2}{*}{ relative frequency of Executive Orders } & 1.096 & 1.226 & 1.183 & 1.426 & 0.947 & 1.462 & 1.074 \\
\hline & {$[0.44]$} & [0.98] & {$[0.70]$} & [0.62] & {$[0.10]$} & {$[0.48]$} & {$[0.33]$} \\
\hline \multirow[t]{2}{*}{ Incumbent NYS Governor is a Republican } & $0.830 *$ & 0.862 & $0.641^{* * *}$ & 0.733 & $1.468^{*}$ & 1.045 & $0.821^{* *}$ \\
\hline & [1.93] & [1.45] & [3.15] & {$[1.21]$} & [1.92] & {$[0.10]$} & [2.06] \\
\hline \multirow[t]{2}{*}{ Incumbent NYC Mayor is a Republican } & $1.226^{\star \star \star}$ & $1.275^{\star \star \star}$ & 1.126 & $1.980 * \star \star$ & $1.335^{\star}$ & 1.195 & $1.216^{\star \star \star}$ \\
\hline & {$[2.76]$} & [3.11] & {$[1.30]$} & [3.42] & {$[1.70]$} & {$[0.54]$} & [2.66] \\
\hline \multirow[t]{2}{*}{ Arthur Ochs Sulzberger publisher dummy } & 1.384 & 1.298 & $1.738 * \star$ & 0.822 & 0.978 & 1.897 & 1.353 \\
\hline & [1.61] & [1.31] & [2.54] & {$[0.45]$} & {$[0.05]$} & {$[0.79]$} & {$[1.50]$} \\
\hline \multirow[t]{2}{*}{ Arthur Sulzberger Jr. publisher dummy } & $1.562^{*}$ & $1.614^{* *}$ & $2.152^{\star \star \star}$ & 0.581 & 0.87 & 4.188 & 1.46 \\
\hline & {$[1.91]$} & [1.99] & [3.07] & {$[0.94]$} & [0.23] & {$[1.40]$} & [1.59] \\
\hline $\begin{array}{l}\mathrm{p} \text { value for no effects of the presidential campaign when } \\
\text { the incumbent President is a Republican }\end{array}$ & 0.38 & 0.62 & 0.63 & 0.06 & 0.29 & 0.04 & 0.65 \\
\hline Monthly dummies & yes & yes & yes & yes & yes & yes & yes \\
\hline Time trend and time trend squared & yes & yes & yes & yes & yes & yes & yes \\
\hline Executive Orders and total number of stories & yes & yes & yes & yes & yes & yes & yes \\
\hline Observations & 444 & 444 & 444 & 444 & 444 & 444 & 444 \\
\hline Pseudo R2 & 0.15 & 0.15 & 0.09 & 0.17 & 0.16 & 0.11 & 0.14 \\
\hline
\end{tabular}

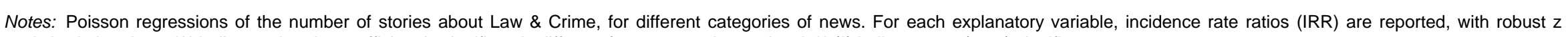
statistics in brackets. ${ }^{\star \star \star}$ indicates that the coefficient is significantly different from zero at the $1 \%$ level. ${ }^{* \star}\left(^{*}\right)$ indicates $5 \%(10 \%)$ significance. 
Table 14: Poisson estimates on the collapsed dataset, entire sample and post-1960 subsample

\begin{tabular}{|c|c|c|c|c|c|c|}
\hline & \multicolumn{3}{|c|}{ entire sample } & \multicolumn{3}{|c|}{ post-1960 subsample } \\
\hline & $\begin{array}{c}{[1]} \\
\text { Democratic stories }\end{array}$ & $\begin{array}{c}{[2]} \\
\text { Defense stories }\end{array}$ & $\begin{array}{c}{[3]} \\
\text { Law \& Crime stories }\end{array}$ & $\begin{array}{c}4] \\
\text { Democratic stories }\end{array}$ & $\begin{array}{c}5] \\
\text { Defense stories }\end{array}$ & $\begin{array}{c}{[6]} \\
\text { Law \& Crime stories }\end{array}$ \\
\hline Incumbent President dummy & $\begin{array}{c}1.180^{\star *} \\
{[2.09]}\end{array}$ & $\begin{array}{l}1.045 \\
{[0.39]}\end{array}$ & $\begin{array}{l}0.968 \\
{[0.42]}\end{array}$ & $\begin{array}{l}1.316^{*} \\
{[1.79]}\end{array}$ & $\begin{array}{l}1.538^{* * *} \\
{[4.12]}\end{array}$ & $\begin{array}{l}0.882 \\
{[0.86]}\end{array}$ \\
\hline Presidential campaign dummy & $\begin{array}{c}1.221^{\star * \star} \\
{[2.76]}\end{array}$ & $\begin{array}{l}0.829 \\
{[1.36]}\end{array}$ & $\begin{array}{l}0.979 \\
{[0.13]}\end{array}$ & $\begin{array}{c}1.252^{\star \star} \\
{[2.52]}\end{array}$ & $\begin{array}{l}1.305 \\
{[1.17]}\end{array}$ & $\begin{array}{l}0.926 \\
{[0.37]}\end{array}$ \\
\hline $\begin{array}{l}\text { interaction: Presidential campaign \& incumbent President } \\
\text { dummy }\end{array}$ & $\begin{array}{l}0.817 \\
{[1.46]}\end{array}$ & $\begin{array}{l}1.043 \\
{[0.23]}\end{array}$ & $\begin{array}{l}1.297 \\
{[1.16]}\end{array}$ & $\begin{array}{l}0.766 \\
{[1.38]}\end{array}$ & $\begin{array}{l}0.574^{\star \star *} \\
{[2.68]}\end{array}$ & $\begin{array}{l}1.342 \\
{[1.26]}\end{array}$ \\
\hline dummy for campaign years with issue ownership reversal & - & $\begin{array}{l}1.451^{*} \\
{[1.94]}\end{array}$ & $\begin{array}{l}0.931 \\
{[0.44]}\end{array}$ & - & $\begin{array}{l}0.984 \\
{[0.05]}\end{array}$ & $\begin{array}{l}0.982 \\
{[0.10]}\end{array}$ \\
\hline number of Killed In action (KIA), thousands & - & $\begin{array}{c}1.919 * \star \star \\
{[4.05]}\end{array}$ & - & - & $\begin{array}{l}1.46 \\
{[1.22]}\end{array}$ & - \\
\hline relative frequency of Executive Orders & $\begin{array}{l}1.036 \\
{[0.16]}\end{array}$ & $\begin{array}{c}2.441^{\star \star} \\
{[2.04]}\end{array}$ & $\begin{array}{c}29.055 \\
{[1.19]}\end{array}$ & $\begin{array}{l}1.038 \\
{[0.18]}\end{array}$ & $\begin{array}{l}2.727^{\star} \\
{[1.95]}\end{array}$ & $\begin{array}{c}28.525 \\
{[1.13]}\end{array}$ \\
\hline $\begin{array}{l}\text { p value for no effects of the campaign when the incumbent } \\
\text { owns the issue }\end{array}$ & 0.98 & 0.42 & 0.09 & 0.82 & 0.15 & 0.13 \\
\hline Time trend and time trend squared & yes & yes & yes & yes & yes & yes \\
\hline Total number of stories & yes & yes & yes & yes & yes & yes \\
\hline Observations & 27 & 27 & 27 & 18 & 18 & 18 \\
\hline Pseudo R2 & 0.1 & 0.28 & 0.16 & 0.12 & 0.36 & 0.13 \\
\hline
\end{tabular}

Notes: Poisson regressions of the total number of stories about Democratic topics, Defense and Law \& Crime. For Democratic stories (columns [1] and [3]) the incumbent President dummy equals one when the incumbent President is a Democrat. Vice versa for Defense and Law \& Crime (columns [2], [3], [5] and [6]). The interaction term is defined accordingly. Campaign years with issue ownership reversal are 1964, 1980 and 1996 for Defense and 1976, 1992 and 1996 for Law \& Crime. For each explanatory variable, incidence rate ratios (IRR) are reported, with robust z statistics in brackets. *** indicates that the coefficient

is significantly different from zero at the $1 \%$ level. ${ }^{\star *}\left({ }^{\star}\right)$ indicates $5 \%(10 \%)$ significance. 
Table A.1: detailed list of Gallup polls on issue ownership. Defense and foreign policy.

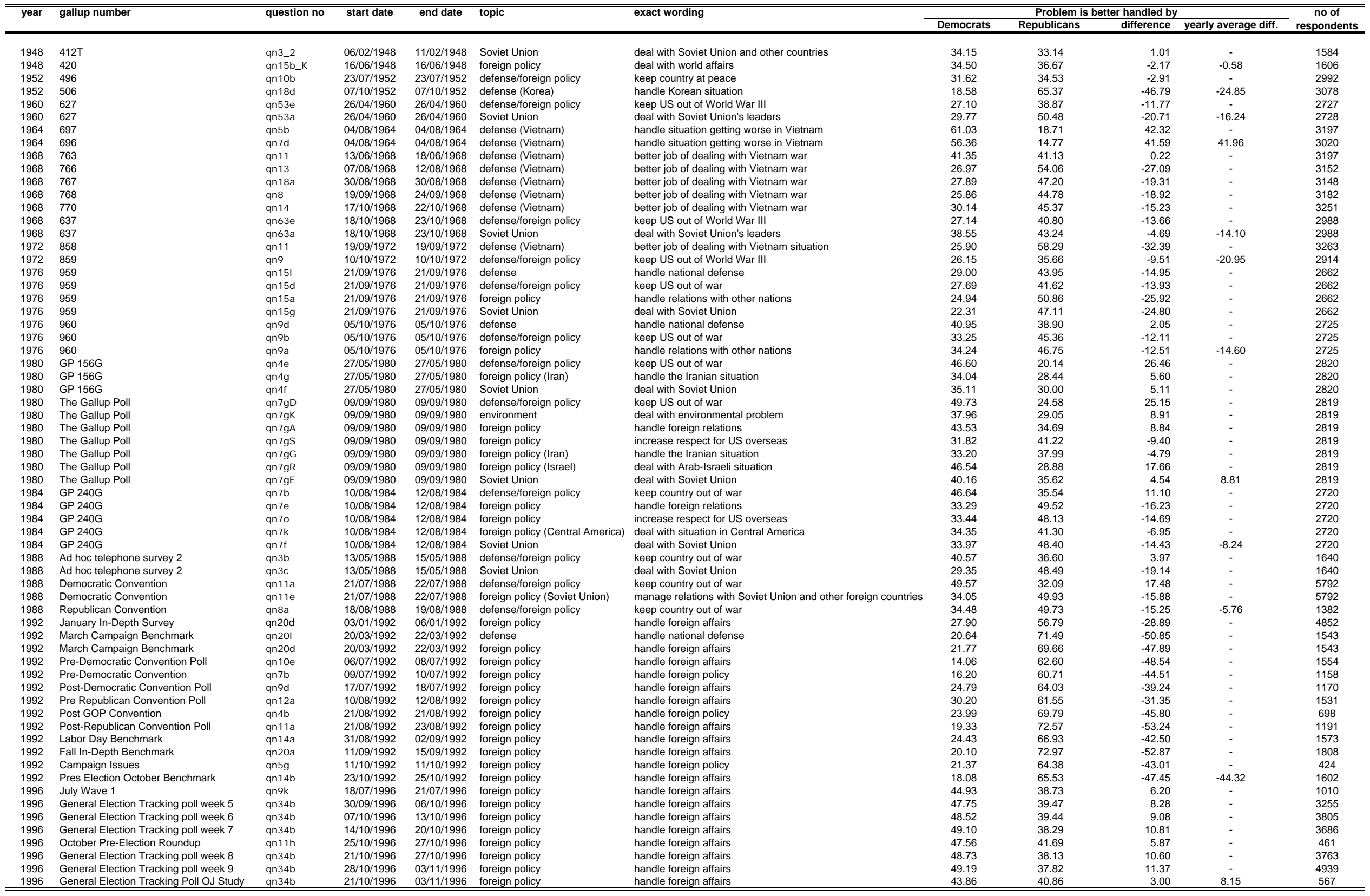


Table A.2: detailed list of Gallup polls on issue ownership. Civil rights, welfare state, health care and crime.

\begin{tabular}{|c|c|c|c|c|c|c|c|c|c|c|c|}
\hline year & gallup number & question no & 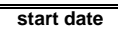 & end date & topic & exact wording & Democrats & $\begin{array}{c}\text { Problem is } \\
\text { Republicans }\end{array}$ & $\frac{\text { er handled by }}{\text { difference }}$ & yearly average diff. & $\begin{array}{c}\text { no of } \\
\text { respondents }\end{array}$ \\
\hline 1956 & 564 & (15) 15 & 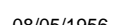 & 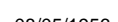 & & he & & & & & \\
\hline 1960 & 627 & ans 53 f & $26 / 04 / 1960$ & $26 / 04 / 1960$ & civil rights & $\begin{array}{l}\text { handle segregatiton (relation between whites and Negroes) } \\
\text { handle racial i itegration in schools }\end{array}$ & 28.41 & $\begin{aligned} 25.99 \\
3038\end{aligned}$ & 2.42 & 2.42 & 1901 \\
\hline 1964 & 696 & qn12 & $04 / 08 / 1964$ & $04 / 08 / 1964$ & civil rights & $\begin{array}{l}\text { nandie racial integration in schools } \\
\text { handle relations between the whites and the Negroes }\end{array}$ & $\begin{array}{l}33.84 \\
49.33\end{array}$ & $\begin{array}{l}30.38 \\
17.51\end{array}$ & $\begin{array}{r}3.46 \\
31.82\end{array}$ & & $\begin{array}{l}2722 \\
3513\end{array}$ \\
\hline 1964 & 696 & gn97 & $04 / 08 / 1964$ & $04 / 08 / 1964$ & civil rights & $\begin{array}{l}\text { handle situation between whites and Negroes getting worse }\end{array}$ & 57.22 & 19.16 & 38.06 & 34.94 & 3513 \\
\hline 1968 & 637 & gn $63 f$ & 18/10/1968 & 23/10/1968 & civil rights & $\begin{array}{l}\text { handle racial integration in schools } \\
\text { s. }\end{array}$ & 35.04 & 23.93 & 11.11 & 11.11 & 2988 \\
\hline 1976 & 959 & gn15r & 21/09/1976 & 21/09/1976 & civil rights & 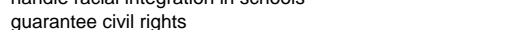 & 42.37 & 25.39 & 16.98 & 16.98 & 2662 \\
\hline 1980 & GP 156G & gn4h & $27 / 05 / 1980$ & $27 / 05 / 1980$ & civil rights & deal with racial problems & 41.13 & 19.50 & 21.63 & & 2820 \\
\hline 1980 & The Gallup Poll & gn7gH & 09/09/1980 & 09/09/1980 & civil rights & deal with racial problems & 46.93 & 25.01 & 21.92 & & 2819 \\
\hline 1980 & The Gallup Poll & an7ad & $09 / 09 / 1980$ & $09 / 09 / 1980$ & civil rights & $\begin{array}{l}\text { improve things for minorities (incl. blacks and Hispanics) } \\
\text { ing }\end{array}$ & 48.32 & 21.21 & 27.11 & 23.55 & 2819 \\
\hline 1984 & GP $240 \mathrm{G}$ & (n) & 10/18/19984 & 12/208/1984 & civin rights & 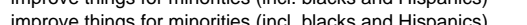 & 5438 & 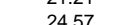 & 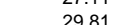 & $\begin{array}{l}29 \\
2981\end{array}$ & 2770 \\
\hline 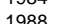 & A d hes telonhone surey 2 & 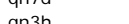 & 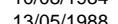 & 15/15/1988 & civil rimbtcs & 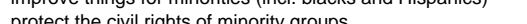 & 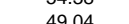 & 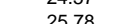 & 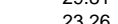 & 的 & (1140 \\
\hline 1992 & January In-Depth Survey & gn20g & 03/01/1992 & 06/01/1992 & 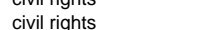 & $\begin{array}{l}\text { handle race relations } \\
\text { haturis }\end{array}$ & 50.76 & 30.44 & 20.32 & & 4852 \\
\hline 1992 & March Campaign Benchmark & qn20g & 20/03/1992 & 22/03/1992 & 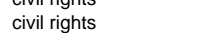 & handle race relations & 40.32 & 41.73 & -1.41 & - & 1543 \\
\hline 1992 & May Wave 1 & qn21 & 07/05/1992 & 10/05/1992 & civil rights & improve conditions for minorities in urban areas & 35.74 & 21.40 & $\begin{array}{l}-1.41 \\
14.34\end{array}$ & : & $\begin{array}{l}1543 \\
4007\end{array}$ \\
\hline 1992 & Pre-Democratic Convention & $\begin{array}{l}q 01 \\
\text { qn7d }\end{array}$ & 09/07/1992 & $10 / 07 / 1992$ & 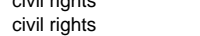 & $\begin{array}{l}\text { handle race relations } \\
\text {. }\end{array}$ & 38.89 & 23.63 & $\begin{array}{l}14.34 \\
15.26\end{array}$ & - & 1158 \\
\hline 1992 & Post-Democratic Convention Poll & qn9g & $17 / 07 / 1992$ & $18 / 07 / 1992$ & civil rights & handle race relations & 57.57 & 22.27 & 35.30 & 16.76 & 1170 \\
\hline 1996 & July Wave 1 & qn9j & 18/07/1996 & 21/07/1996 & civil rights & handle gay marriages & 41.33 & 26.87 & 14.46 & 14.46 & 1010 \\
\hline 1976 & 959 & qn15m & $21 / 09 / 1976$ & $21 / 09 / 1976$ & welfare state & deal with welfare situation & 51.88 & 25.54 & 26.34 & & 2662 \\
\hline 1976 & 959 & qn15p & 21/09/1976 & $21 / 09 / 1976$ & welfare state & provide for the poor and the elderly & 57.48 & 23.59 & 33.89 & 30.12 & 2662 \\
\hline 1980 & The Gallup Poll & qn7go & 09/09/1980 & 09/09/1980 & welfare state & help the poor and needy & 48.00 & 22.92 & 25.08 & 25.08 & 2819 \\
\hline 1984 & GP 240G & qn71 & 10/08/1984 & $12 / 08 / 1984$ & welfare state & help the poor and needy & 59.61 & 24.94 & 34.67 & 34.67 & 2720 \\
\hline 1988 & Ad hoc telephone survey 2 & gn3f & $13 / 05 / 1988$ & $15 / 05 / 1988$ & welfare state & help the poor and needy & 53.81 & 24.41 & 29.40 & 29.40 & 1640 \\
\hline 1992 & January In-Depth Survey & gn20h & 03/01/1992 & $06 / 01 / 1992$ & welfare state & handle poverty and homelessness & 62.16 & 23.98 & 38.18 & & 4852 \\
\hline 1992 & March Campaign Benchmark & gn20h & $20 / 03 / 1992$ & $22 / 03 / 1992$ & welfare state & handle poverty and homelessness & 58.07 & 25.65 & 32.42 & 35.30 & 1543 \\
\hline 1996 & April Wave 11 . & gn17e & $09 / 04 / 1996$ & $10 / 04 / 1996$ & handle welfare & welfare state & 50.32 & 37.42 & 1290 & - & 1010 \\
\hline 1996 & July Wave 1 & qn9b & $18 / 07 / 1996$ & $21 / 07 / 1996$ & handle welfare policy & welfare state & 48.55 & 30.94 & 17.61 & & 1010 \\
\hline 1996 & October Pre-Election Roundup & qn11b & 25/10/1996 & $27 / 10 / 1996$ & handle welfare policy & welfare state & 56.05 & 36.60 & 19.45 & 16.65 & 461 \\
\hline 1992 & January In-Depth Survey & gn20c & $03 / 01 / 1992$ & $06 / 01 / 1992$ & health care & handle health care policy & 5939 & 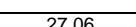 & 32.33 & -5 & 4852 \\
\hline $\begin{array}{l}1992 \\
1992\end{array}$ & $\begin{array}{l}\text { January In-Depth Survey } \\
\text { March Campaign Benchmark }\end{array}$ & $\begin{array}{l}\text { qn20c } \\
\text { qn20c }\end{array}$ & $\begin{array}{l}\text { 03/01/1992 } \\
20 / 03 / 1992\end{array}$ & $\begin{array}{l}06 / 101 / 1992 \\
22 / 1 / 1992\end{array}$ & $\begin{array}{l}\text { nealth care } \\
\text { health care }\end{array}$ & $\begin{array}{l}\text { handile health care polily } \\
\text { handle health care policy }\end{array}$ & $\begin{array}{l}59.39 \\
54.23\end{array}$ & $\begin{array}{l}27.06 \\
31.26\end{array}$ & $\begin{array}{l}32.33 \\
22.97\end{array}$ & : & $\begin{array}{l}4852 \\
1543\end{array}$ \\
\hline 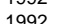 & Pre- Demorratic Convention Poll & 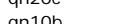 & 0 & 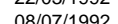 & health care & hande hasth care nolicy & 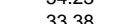 & 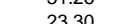 & 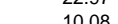 & . & 1554 \\
\hline 1992 & Post-Democratic Convention Poll & gn9c & $17 / 07 / 1992$ & $18 / 07 / 1992$ & health care & handle health care policy & $\begin{array}{l}30.90 \\
61.94\end{array}$ & 20.30 & 41.64 & - & 1170 \\
\hline 1992 & Post GOP Convention & qn4g & $21 / 08 / 1992$ & $21 / 08 / 1992$ & health care & $\begin{array}{l}\text { handle health care } \\
\text { hercy }\end{array}$ & $\begin{array}{l}01.94 \\
58.08\end{array}$ & 32.12 & $\begin{array}{l}41.04 \\
25.96\end{array}$ & . & 698 \\
\hline 1992 & Post-Republican Convention Poll & qn11e & $21 / 08 / 1992$ & $23 / 08 / 1992$ & health care & $\begin{array}{l}\text { handle health care policy } \\
\text { hate }\end{array}$ & 54.29 & $\begin{array}{l}32.54 \\
32.54\end{array}$ & 21.75 & : & 1191 \\
\hline 1992 & Labor Day Benchmark & gn14e & $31 / 08 / 1992$ & $\begin{array}{l}23 / 108 / 19992 \\
02 / 1992\end{array}$ & $\begin{array}{l}\text { nealuc care } \\
\text { health care }\end{array}$ & $\begin{array}{l}\text { nanale } \\
\text { handle health care policy }\end{array}$ & $\begin{array}{l}54.29 \\
61.70\end{array}$ & $\begin{array}{l}32.54 \\
26.76\end{array}$ & $\begin{array}{l}21.15 \\
34.94\end{array}$ & . & 1573 \\
\hline 1992 & $\begin{array}{l}\text { Campaign Issues } \\
\text { Inik }\end{array}$ & qn5h & $11 / 10 / 1992$ & $11 / 10 / 1992$ & $\begin{array}{l}\text { health care } \\
\text { her }\end{array}$ & $\begin{array}{l}\text { handle health care } \\
\text { hericy }\end{array}$ & 58.05 & 22.84 & $\begin{array}{l}35.21 \\
35.21\end{array}$ & - & 424 \\
\hline 1992 & Pres Election October Benchmark & qn14f & 23/10/1992 & $25 / 10 / 1992$ & health care & handle health care & 49.56 & 23.55 & 26.01 & 27.88 & 1602 \\
\hline 1996 & April Wave 1 . & qn17d & 09/04/1996 136 & $10 / 04 / 1996$ & health care & handle health care & 55.68 & 33.76 & 21.92 & 27.00 & 1010 \\
\hline 1996 & July Wave 1 & qn9e & $18 / 07 / 1996$ & $21 / 07 / 1996$ & health care & handle Medicare & 49.18 & 30.07 & 19.11 & - & 1010 \\
\hline 1996 & 1996 Election & qn12c & 05/08/1996 & 07/08/1996 & health care & handle Medicare & 48.86 & 30.33 & 18.53 & - & 986 \\
\hline 1996 & General Election Tracking poll week 5 & qn34h & 30/09/1996 & 06/10/1996 & health care & handle Medicare & 49.97 & 29.07 & 20.90 & - & 1601 \\
\hline 1996 & General Election Tracking poll week 6 & qn34h & 07/10/1996 & $13 / 10 / 1996$ & health care & handle Medicare & 51.11 & 30.03 & 21.08 & & 3805 \\
\hline 1996 & General Election Tracking poll week 7 & gn34h & $14 / 10 / 1996$ & 20/10/1996 & health care & handle Medicare & 50.37 & 30.26 & 20.11 & - & 3686 \\
\hline 1996 & $\begin{array}{l}\text { October Pre-Election Roundup } \\
\text { Ond }\end{array}$ & gn11c & $25 / 10 / 1996$ & $27 / 10 / 1996$ & health care & $\begin{array}{l}\text { handle health care policy } \\
\text { hes }\end{array}$ & 60.50 & 33.62 & 26.88 & - & 461 \\
\hline 1996 & October Pre-Election Roundup & qn11e & 25/10/1996 & $27 / 10 / 1996$ & health care & $\begin{array}{l}\text { handle Medicare } \\
\text { hour }\end{array}$ & 56.69 & 36.27 & 20.42 & 21.12 & 461 \\
\hline 1972 & 858 & gn12 & $19 / 09 / 1972$ & $19 / 09 / 1972$ & crime & better job of dealing with crime and lawlessness & 26.23 & 50.05 & -23.82 & -23.82 & 3263 \\
\hline $\begin{array}{l}19 / 2 \\
1988\end{array}$ & $\begin{array}{l}\text { 858 } \\
\text { Republican Convention }\end{array}$ & $\begin{array}{l}\text { qn12 } \\
\text { qn8d }\end{array}$ & $\begin{array}{l}190 / 09 / 19 / 2 \\
18 / 08 / 1988\end{array}$ & $\begin{array}{l}19 / 099 / 1972 \\
19 / 08 / 1988\end{array}$ & $\begin{array}{l}\text { crime } \\
\text { crime }\end{array}$ & $\begin{array}{l}\text { Detter job of dealing with crime and lawlessness } \\
\text { fight crime }\end{array}$ & $\begin{array}{l}26.23 \\
33.97\end{array}$ & $\begin{array}{l}50.05 \\
43.27\end{array}$ & $\begin{array}{r}-23.82 \\
-9.30\end{array}$ & $\begin{array}{l}-23.82 \\
-9.30\end{array}$ & $\begin{array}{l}3263 \\
1382\end{array}$ \\
\hline 1992 & Pre-Democratic Convention & gn7c & $09 / 07 / 1992$ & $10 / 07 / 1992$ & crime & handle crime & 24.80 & 24.43 & 0.37 & -0 & 1158 \\
\hline 1992 & Pre Republican Convention Poll & gn12e & 10/08/1992 & $12 / 08 / 1992$ & crime & handle crime and drugs & 51.15 & 34.66 & 16.49 & . & 1531 \\
\hline 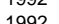 & $\begin{array}{l}\text { Post GOP Convention } \\
\text { Post }\end{array}$ & 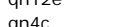 & 210811992 & $21 / 08 / 1992$ & crime & handle crime & 41. & 40. & 0.41 & . & 698 \\
\hline 1992 & Fall Tracking Poll & an11b & $\begin{array}{l}210011952 \\
09 / 10 / 1992\end{array}$ & 11/10/1992 & crime & handle crime & $\begin{array}{l}41.50 \\
39.07\end{array}$ & 33.56 & 5.41 & : & 1567 \\
\hline 1992 & Campaign Issues & gn5e & $11 / 10 / 1992$ & $11 / 10 / 1992$ & crime & handle crime & 34. & 35.88 & -1.84 & & 424 \\
\hline 1992 & Pres Election October Benchmark & gn14g & 23/10/1992 & $25 / 10 / 1992$ & crime & handle crime & 31. & 29 & 2. & 3.94 & 1602 \\
\hline 1996 & $\begin{array}{l}\text { July Wave } 1 \\
\text {. }\end{array}$ & qns & 352 & 35267 & crime & le crime & 43. & 34. & 9. & & 1010 \\
\hline $\begin{array}{l}1996 \\
1996\end{array}$ & 1996 Ele & & & & $\begin{array}{l}\text { Crime } \\
\text { crime }\end{array}$ & handle crime & 43 & 33. & 10.16 & - & 986 \\
\hline $\begin{array}{l}1996 \\
1996\end{array}$ & $\begin{array}{l}1996 \text { Election } \\
\text { General Election Tracking poll week } 4\end{array}$ & gn 3 & $\begin{array}{l}35282 \\
35331\end{array}$ & 35337 & $\begin{array}{l}\text { Crme } \\
\text { crime }\end{array}$ & gabuse & 44.66 & 37. & 6.97 & : & 1109 \\
\hline $\begin{array}{l}1996 \\
1996\end{array}$ & $\begin{array}{l}\text { Ocheral } \\
\text { October Pre-Election Roundup }\end{array}$ & qn11g & $\begin{array}{l}35331 \\
35363\end{array}$ & $\begin{array}{l}35331 \\
35365\end{array}$ & crime & $\begin{array}{l}\text { handle crime } \\
\text { hese }\end{array}$ & $\begin{array}{l}44.00 \\
53.9\end{array}$ & 37.71 & 16.19 & & 461 \\
\hline $\begin{array}{l}1990 \\
1996\end{array}$ & General Election Tracking Poll OJ Study & gn31 & $\begin{array}{l}35303 \\
35359\end{array}$ & $\begin{array}{l}35305 \\
35372\end{array}$ & crime & handle drug abuse & 44.3 & 37.89 & $\begin{array}{r}10.199 \\
6.41\end{array}$ & 9.79 & $\begin{array}{l}401 \\
1129\end{array}$ \\
\hline
\end{tabular}


Table A.3: National Election Study data on Most Important Problem and Issue Ownership, 1972-1996

\begin{tabular}{|c|c|c|c|c|c|c|c|c|c|}
\hline \multirow[t]{2}{*}{ year } & \multicolumn{2}{|c|}{ racial problems [8] } & \multicolumn{2}{|c|}{ social welfare [9] } & \multicolumn{2}{|c|}{ public order [7] } & \multicolumn{2}{|c|}{ defense \& foreign affairs [3] } & \multirow{2}{*}{$\begin{array}{c}\text { no of } \\
\text { respondents }\end{array}$} \\
\hline & \% MIP & \% Dem. Adv. & \% MIP & \% Dem. Adv. & \% MIP & \% Dem. Adv. & \% MIP & \% Dem. Adv. & \\
\hline 1972 & 6.54 & 10.94 & 10.76 & 27.36 & 19.62 & -11.40 & 33.90 & -10.09 & 994 \\
\hline 1976 & 0.80 & 14.29 & 34.85 & 43.49 & 8.15 & 9.15 & 5.11 & -6.74 & 1742 \\
\hline 1980 & 0.07 & -100 & 14.83 & -4.06 & 1.48 & -15.00 & 32.10 & -28.21 & 1349 \\
\hline 1984 & 0.39 & 85.71 & 23.31 & 11.89 & 4.04 & -38.89 & 33.48 & -7.78 & 1780 \\
\hline 1988 & 0.84 & 42.86 & 21.97 & 25.82 & 20.82 & -3.21 & 9.72 & -15.72 & 1657 \\
\hline 1992 & 1.26 & 41.67 & 37.09 & 42.07 & 11.86 & -19.11 & 3.15 & 11.86 & 1906 \\
\hline 1996 & 2.96 & 45.45 & 37.58 & 25.27 & 28.57 & -13.08 & 4.38 & 3.45 & 777 \\
\hline
\end{tabular}

Notes: data being used in table 1 are highlighted 